\title{
Cassava Bioethanol
}

\author{
Klanarong Sriroth ${ }^{1}$, Sittichoke Wanlapatit ${ }^{2}$ \\ and Kuakoon Piyachomkwan ${ }^{2}$ \\ ${ }^{1}$ Dept. of Biotechnology, Faculty of Agro-Industry, \\ Kasetsart University, Bangkok \\ ${ }^{2}$ Cassava and Starch Technology Research Unit, \\ National Center for Genetic Engineering and Biotechnology (BIOTEC) \\ Thailand
}

\section{Introduction}

\subsection{Cassava}

Cassava (Manihot esculenta Crantz) is a shrubby perennial crop in the Family of Euphorbiaceae. It is also named others, depending upon geographic regions such as yucca in Central America, mandioca or manioca in Brazil, tapioca in India and Malaysia and cassada or cassava in Africa and Southeast Asia. Cassava is mostly cultivated in tropics of Africa, Latin America and Asia, located in the equatorial belt, between $30^{\circ}$ north and $30^{\circ}$ south. The crop produces edible starch-reserving roots which have long been employed as an important staple food for millions of mankind as well as animal feed. Due to the fact of ease of plantation and low input requirement, cassava is mostly cultivated in marginal land by poor farmers and is sometimes named as the crop of the poor. In these planting areas, cassava plays an essential role not only as food security, but also income generation. In addition to a primary use for direct consumption and animal feed, starch-rich roots are good raw materials for industrial production of commercial tapioca starch, having excellent characteristics of high whiteness, odorless and tasteless and when cooked, yielding high paste viscosity, clarity and stability. The distinct attributes of extracted cassava starch, either as native or modified form, are very attractive for a broad range of food and non-food application including paper, textile, pharmaceutical, building materials and adhesives. Furthermore, cassava starch is extensively utilized for a production of sweeteners and derivatives including glucose syrup, fructose syrup, sugar alcohols (e.g. sorbitol, mannitol), and organic acids (e.g. lactic acid, citric acid). The application of cassava as renewable feedstock is now expanded to biorefinery, i.e. a facility that integrates processes and equipment to produce fuels, power, chemicals and materials from biomass (Fernando et al., 2006). With this regard, cassava is signified as a very important commercial crop that can have the value chain from low-valued farm produces to high-valued, commercialized products.

\subsection{Cassava agronomy and plantation}

Cassava is well recognized for its excellent tolerance to drought and capability to grow in impoverished soils. The plant can grow in all soil types even in infertile soil or acid soil $(\mathrm{pH}$ 
4.2-4.5), but not in alkaline soil $(\mathrm{pH}>8)$. Despite of that, cassava prefers loosen-structured soil such as light sandy loams and loamy sands for its root formation. As the drought tolerant crop, cassava can be planted in the lands having the rainfall less than $1,000 \mathrm{~mm}$ or unpredictable rainfall. Rather than seeding, the plants are propagated vegetatively from stem cuttings or stakes, having $20-\mathrm{cm}$ in length and at least 4 nodes. To ensure good propagation, good-quality stakes obtained from mature plants with 9-12 months old should be used. The appropriate time of planting is usually at an early period of rainy seasons when the soil has adequate moisture for stake germination. When planted, the stakes are pushed into the soil horizontally, vertically or slanted; depending on soil structure. For loosen and friable soil, the stakes are planted by pushing vertically ("standing"), or slanted approximately $10 \mathrm{~cm}$ in depth below the soil surface with the buds facing upward. This planting method gives higher root yields, better plant survival rates and is easy for plant cultivation and root harvest (Howeler, 2007). The horizontal planting is suited for heavy clay soils. Planting with $100 \times 100 \mathrm{~cm}$ spacing (or 10,000 plants/hectare) is typical, however, less spacing $(100 \times 80 \mathrm{~cm}$ or $80 \times 80 \mathrm{~cm})$ and larger spacing $(100 \times 120 \mathrm{~cm}$ or $120 \times 120 \mathrm{~cm})$ are recommended for infertile sandy soil and fertile soil, respectively. At maturity stage with 818 months after planting, the plants with two big branches (i.e. dichotomous branching) or three branches (i.e. trichotomous branching) are $1-5 \mathrm{~m}$ in height with the starchaccumulating roots extending radially $1 \mathrm{~m}$ into the soil. Mature roots are different in shapes (as conical, conical-cylindrical, cylindrical and fusiforms), in sizes (ranging from 3 to $15 \mathrm{~cm}$ in diameter, as influenced by variety, age and growth conditions) and in peel colors (including white, dark brown and light brown). Although the roots can be harvested at any time between 6-18 months, it is typically to be harvested on average at 10-12 months after planting. Early or late harvesting may lower root yields and root starch contents. Still, the actual practice of farmers is depending on economic factors, i.e. market demand and root prices. Root harvesting can be accomplished manually by cutting the stem at a height of 40 $60 \mathrm{~cm}$ above the ground and roots are then pulled out by using the iron or woody stalk with a fulcrum point in between the branches of the plant. Plant tops are cut into pieces for replanting, leaves are used for making animal fodder and roots are delivered to the market for direct consumption or to processing areas for subsequent conversion to primary products as flour, chips and starch.

\subsection{Cassava production}

Since 2004, the world production of cassava roots has been greater than 200 million tons and reaches 240 million tons in 2009 (Food and Agriculture Organization [FAO], 2011; Table 1). The major cassava producers are located in three continental regions which are Nigeria, Brazil and Thailand, accounting approximately for 20, 11 and $12 \%$ of total world production, respectively. In the last two decades, the world production of cassava continuously increases (Table 1), as primarily driven by the market demand, in particular an expansion of global starch market. The growth rate of root production in the last decade (2000-2009) is even greater than the previous one (1990-1999) due to markedly rising demand of cassava for bioethanol production in Asia especially in China and Thailand. Interestingly, the root productivity of cassava has been dramatically increased in some countries including Vietnam, India, Indonesia and Thailand by 8.46, 7.46, 6.22 and 5.85 tons/hectare in the past 10 years. The root productivity of India is the greatest (34.37 tons/hectare), followed by Thailand (22.68 tons/hectare) and Vietnam (16.82 tons/hectare) while the world average is 


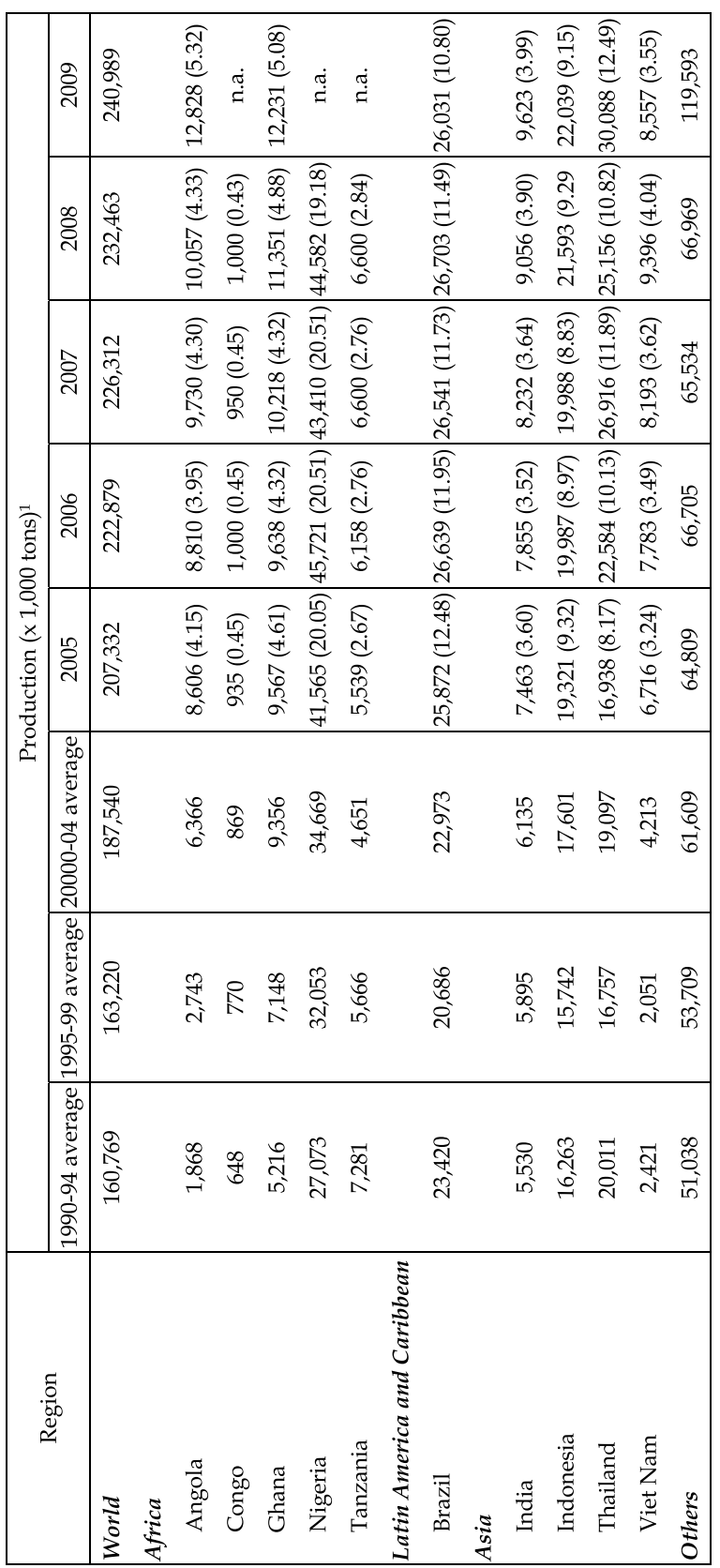

${ }^{1}$ The numbers in parenthesis represent the percentage of total world production. n.a. $=$ not available

Source: Food and Agriculture Organization of the United Nations [FAO], 2011

Table 1. Annual production of cassava roots by major producers. 
12.64 tons/hectare (Table 2). The world leading cassava producers, i.e. Nigeria and Brazil, however, do not have much improvement in root productivities in the past 10 years; only by 2.10 tons/hectare (from 9.70 to 11.80 tons/hectare since 2000 to 2008) and by 0.35 tons/hectare (from 13.55 to 13.90 tons/hectare since 2000 to 2009), respectively.

The production of cassava can be simply increased by expanding planting areas. Nevertheless, in most regions, no new marginal land is accessible as well as forestry areas are not allowed for area expansion. Moreover, in some countries, there is a competition for land uses among other economic crops such as sugar cane and maize in Thailand. The sustainable and effective means of increasing root production should be achieved by an increase in root productivity. Yields or root productivities of cassava roots vary significantly with varieties, growing conditions such as soil, climate, rainfall as well as agronomic practices. Better root yields can be obtained by well-managed farm practices including time of planting (early of a wet season), land preparation (plowing by hand or mechanically and ridging), preparation of planting materials (ages of mother plants, storage of stems, length \& angle of cuttings, chemical treatment), planting method (position, depth of planting and spacing), fertilization (type of fertilizers - chemical vs. organic, dose , time and method of fertilizer application), erosion control, weed control, irrigation and intercropping (Howeler, 2001; 2007). The agronomic practices implemented by farmers vary markedly from regions to regions, depending greatly on farm size, availability of labor, soil and climatic conditions as well as socio-economic circumstances of each region (Table 3). It is very interesting to note that the highest root productivity was reported in India (i.e. 40 tons/hectare) which was irrigated cassava rather than rainfed one, with a highest amount of fertilizer application. In some planting areas such as in Thailand, irrigation is now introduced instead of relying only on rainfall. Yet, the investment cost is high and farmer's decision is upto market demand, price of cassava roots as well as other competitive crops. By effective farm management, it is expected that the root productivity can be increased twice, from 25 to 50 tons/hectare. By combining that with varietal improvement, the root productivity can be potentially improved upto 80 tons/hectare (Tanticharoen, 2009).

The production cost of cassava is classified into fixed costs and variable costs. The fixed costs include land rent, machinery, depreciation cost and taxes. The variable costs are consisted of labor costs (for land preparation, planting material preparation, planting, fertilizer \& chemical application, weeding, harvesting and irrigation) and others including planting materials, chemicals (herbicides, sacks), fuels and tools. Except China, all countries demonstrate that the labor cost is greater than $40 \%$ of total production cost. In particular, the labor cost as well as the fixed costs of cassava plantation in India is quite high comparatively to other countries, making their production cost quite high. A semi-mechanized practice for cassava plantation is therefore developed in some countries such as Brazil and Thailand in order to minimize the labor cost, and hence total production cost.

\subsection{Cassava attributes}

Cassava plants photosynthesize and store solar energy in a form of carbohydrate, mainly as starch in edible, underground roots. The roots are very moist having the water content around $59-79 \% \mathrm{w} / \mathrm{w}$ (Table 4). On dry solid basis, starch is a major component of cassava roots, accounting upto $77-94 \% \mathrm{w} / \mathrm{w}$, the rests are protein $(1.7-3.8 \% \mathrm{w} / \mathrm{w})$, lipid $(0.2-1.4 \%$ $\mathrm{w} / \mathrm{w})$, fiber $(1.5-3.7 \% \mathrm{w} / \mathrm{w}$ as crude fiber, i.e. cellulose and lignin) and ash $(1.8-2.5 \% \mathrm{w} / \mathrm{w})$ (Table 4). Some sugars, i.e. sucrose, glucose and fructose are also found in storage roots at $4-8 \% \mathrm{w} / \mathrm{w}$ (dry basis). In addition to cellulosic fiber, the roots also contain non-starch 


\begin{tabular}{|c|c|c|c|c|c|c|c|}
\hline & ठ્ণે & 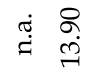 & $\begin{array}{l}\infty \\
\stackrel{\sim}{0} \\
\text { in }\end{array}$ & 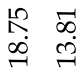 & 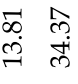 & $\begin{array}{l}0 \\
0 \\
\stackrel{0}{0}\end{array}$ & $\begin{array}{l}\text { ¿゙ } \\
\text { i }\end{array}$ \\
\hline & $\begin{array}{l}\infty \\
\stackrel{ }{े}\end{array}$ & $\begin{array}{l}\infty \\
\stackrel{\#}{\rightleftarrows} \\
\stackrel{+}{\sharp}\end{array}$ & 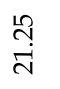 & 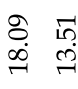 & 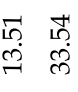 & б్ & $\stackrel{\substack{7 \\
\text { I }}}{ }$ \\
\hline & ठ્ণે & 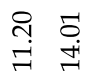 & $\begin{array}{l}\text { ส̃ } \\
\text { הิ }\end{array}$ & 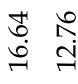 & 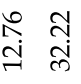 & 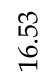 & $\underset{\stackrel{I}{I}}{ت}$ \\
\hline & ఫ్̊․ & 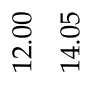 & $\begin{array}{l}\text { ळे } \\
\dot{\vec{\lambda}}\end{array}$ & 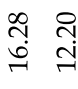 & 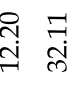 & 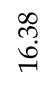 & $\underset{\mathfrak{I}}{\stackrel{\mathfrak{I}}{ }}$ \\
\hline 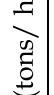 & 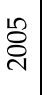 & 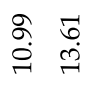 & $\stackrel{\infty}{\stackrel{-}{\sim}}$ & 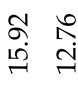 & 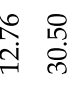 & 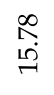 & 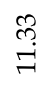 \\
\hline $\begin{array}{l}\frac{1}{\tilde{U}} \\
\bar{z} \\
0 \\
0 \\
0\end{array}$ & 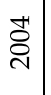 & 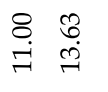 & $\begin{array}{l}\stackrel{\infty}{N} \\
\stackrel{N}{\Lambda}\end{array}$ & 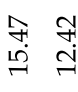 & 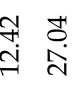 & $\stackrel{\infty}{\stackrel{\infty}{+}}$ & సે \\
\hline & 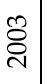 & $\begin{array}{l}\stackrel{H}{H} \\
\stackrel{9}{\circ}\end{array}$ & $\begin{array}{l}\text { ले } \\
\text { ळे }\end{array}$ & 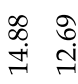 & 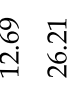 & $\begin{array}{l}\stackrel{\infty}{\sim} \\
\underset{\sim}{\sim}\end{array}$ & $\begin{array}{l}\Omega \\
\vdots \\
0\end{array}$ \\
\hline & ઠे & 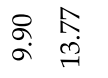 & $\begin{array}{l}\hat{0} \\
\text { ㄱ. }\end{array}$ & 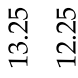 & 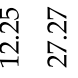 & 굴 & $\begin{array}{l}\Sigma \\
\text { ลิ } \\
0\end{array}$ \\
\hline & Бे & 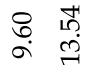 & 菅 & 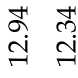 & 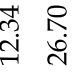 & 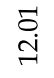 & $\underset{\substack{\infty \\
0}}{0}$ \\
\hline & ઠ્ণ & 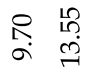 & $\begin{array}{l}\infty \\
\infty \\
\stackrel{0}{0}\end{array}$ & 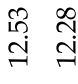 & 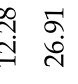 & $\begin{array}{l}\infty \\
\infty \\
\infty\end{array}$ & 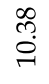 \\
\hline 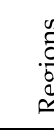 & 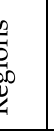 & 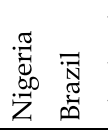 & 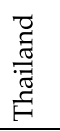 & 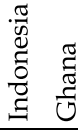 & 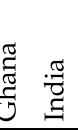 & 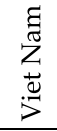 & $\begin{array}{l}\overline{0} \\
\overrightarrow{0} \\
3\end{array}$ \\
\hline
\end{tabular}

n.a. $=$ not available

Source: Food and Agriculture Organization of the United Nations [FAO], 2011

Table 2. World average root productivity (tons/ hectare) and those of major producers. 


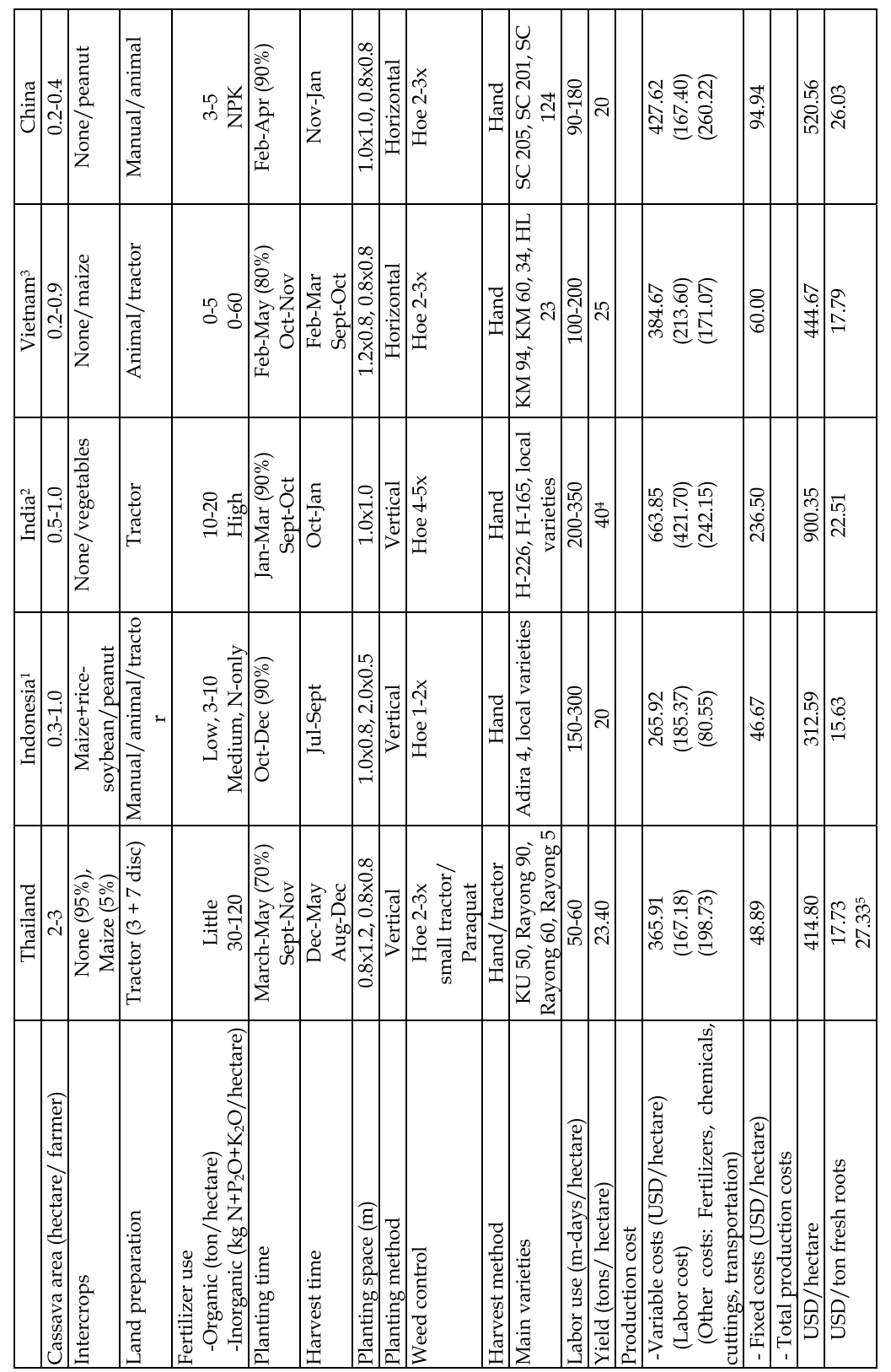

${ }^{1}$ Information of Java and Sumatra ${ }^{2}$ Information of Tamil Nadu ${ }^{3}$ Information of South Vietnam ${ }^{4}$ Irrigated cassava ${ }^{5}$ Source: Office of Agricultural Futures Trading Commission [AFTC], 2007 n.a. = not available Source: Howeler, 2001

Table 3. Agronomic practices and production cost of cassava plantation in some Asian countries. 


\begin{tabular}{|c|c|c|c|c|c|c|c|c|c|}
\hline \multirow{2}{*}{ Composition ${ }^{1}$} & \multicolumn{6}{|c|}{ Grains } & \multirow{2}{*}{$\begin{array}{l}\text { Tubers } \\
\text { Potato }^{3}\end{array}$} & \multirow{2}{*}{\begin{tabular}{|c|} 
Roots \\
Cassava $^{4}$ \\
\end{tabular}} & \multirow{2}{*}{$\begin{array}{l}\text { Cassava } \\
\text { chips }\end{array}$} \\
\hline & Maize & Wheat & Barley & Sorghum & Rye & Rice $^{2}$ & & & \\
\hline Moisture & $12-15$ & $11-14$ & $11-14$ & $11-14$ & 11-14 & 14 & 78 & $59-70$ & 14 \\
\hline Starch & $65-72$ & $62-70$ & $52-64$ & $72-75$ & $52-65$ & 685 & 775 & 770 & 77 \\
\hline Sugar & 2.2 & n.a. & n.a. & n.a. & n.a. & $60^{\circ}$ & $1 / 5$ & $7 /-94$ & n.a. \\
\hline Protein & $9-12$ & $12-14$ & $10-11$ & 11.2 & $10-15$ & 6.6 & 10 & $1.7-3.8$ & 3.1 \\
\hline Lipid & 4.5 & 3 & $2.5-3$ & 3.6 & $2-3$ & 1.9 & 0.4 & $0.2-1.4$ & 1.1 \\
\hline $\begin{array}{l}\text { Fiber/ Cell } \\
\text { wall materials }\end{array}$ & 9.6 & 11.4 & 14 & n.a. & n.a. & 16.1 & 1.8 & $1.5-3.7^{6}$ & 3.1 \\
\hline Ash & 1.5 & 2 & 2.3 & 1.7 & 2 & 4.0 & 4.5 & $1.8-2.5$ & 1.4 \\
\hline
\end{tabular}

$1 \% \mathrm{w} / \mathrm{w}$ (dry basis) except moisture content reported as \% $\mathrm{w} / \mathrm{w}$ (wet basis)

${ }^{2}$ As paddy rice (Juliano, 1993)

${ }^{3}$ Source: Treadway, 1967

${ }^{4}$ Source: Breuninger et al., 2009

${ }^{5}$ As starch and sugar content

${ }^{6}$ As crude fiber content.

n.a. $=$ not available

Source: Monceaux, 2009

Table 4. Chemical composition of starch-accumulating edible parts of various starch crops.

polysaccharides, i.e. hemicellulose and pectic substances as evidenced by a presence of monosaccharide including rhamnose, fucose, arabinose, xylose, mannose, galactose, glucose in hydrolyzed cell wall materials (Kajiwara \& Maeda, 1983; Menoli \& Beleia, 2006; Charles et al., 2008). Some minerals such as sodium, calcium, potassium, magnesium, iron, copper, zinc, manganese and phosphorus are detected in fresh roots as well (Balagopalan et al., 1988; Rojanaridpiched, 1989; Charles et al., 2005).

Unlike grains of cereals having low moisture content (11-15\%), cassava roots contain very high moisture contents and are very perishable. This is a constraint for cassava utilization as roots are subjected to deterioration and spoilage by microorganism attacks during storage. Fresh roots can be stored only a few days and should be transformed to products as soon as they are harvested. To prolong their shelf-life, the roots can be simply chopped and sundried; the final product is named as cassava chip with the moisture content approximately $14 \%$ (Table 4). Cassava roots also contain much lower protein contents than cereals.

The starch content of mature roots can range significantly, depending on genetic traits and environmental factors during plant development, as well as harvest time or ages after planting. Roots collected from crops being planted with the drought during initial state of growth have much lower starch contents and root yields than those from crops without the drought (Pardales and Esquibel, 1996; Santisopasri et al., 2001; Sriroth et al., 2001). Immature or young roots (less than 8 months) provide low starch yields due to low starch contents and root yields. The genetic and environmental growth condition can also influence starch qualities in term of starch composition (amylose and amylopectin content), ease of cooking as indicated by gelatinization or pasting temperature and cooked paste viscosity (Moorthy and Ramanujam, 1986; Asaoka et al., 1991;1992; Defloor et al., 1998; Sriroth et al., 1999; Santisopasri et al., 2001). 


\section{Use of cassava for bioethanol production}

\subsection{Bioethanol production}

Instead of chemical synthesis, the bioprocess, i.e. fermentation of simple sugars by microorganism is nowadays used extensively to produce ethanol from renewable sugarcontaining biomass. Important ones are sugar crops, starch crops, and lignocellulosic materials derived from agricultural residues. The two former ones are recognized as the first generation feedstock for bioethanol production while the last one is the second generation feedstock. When ethanol is produced by yeast fermentation of sugar feedstock such as sugar cane, molasses, sugar beet and sweet sorghum, yeast can directly consume simple sugars and convert them to ethanol. However, starch and cellulose feedstock are a polymer of glucose and cannot directly be utilized by yeast. They have to be converted or depolymerized to glucose prior to yeast fermentation. Depolymerization or hydrolysis of starch is much simpler and more cost effective than that of cellulosic materials and can be achieved by acid or enzyme or a combination of both.

Starch is a polysaccharide comprising solely of glucose monomers which are linked together by glycosidic bonds. It is composed of two types of glucan namely amylose, a linear glucose polymer having only $\alpha-1,4$ glycosidic linkage and amylopectin, a branched glucose polymer containing mainly $\alpha-1,4$ glycosidic linkage in a linear part and a few $\alpha-1,6$ at a branch structure. Most starches contain approximately 20-30\% amylose and the rest are amylopectin. Some starches contain no amylose such as waxy corn starch, waxy rice starch, amylose-free potato, amylose-free cassava and some have very high amylose contents upto $50-70 \%$ as in high amylose maize starches. These two polymers organize themselves into semi-crystalline structure and form into minute granules, which are water insoluble. Starch granules are less susceptible to enzyme hydrolysis. Upon cooking in excess water, the granular structure of starch is disrupted, making glucose polymers become solubilized and more susceptible to enzyme attacks. At the same time, the starch slurry becomes more viscous. This process is known as gelatinization and the temperature at which starch properties are changed is named as gelatinization temperatures. Different starches have different gelatinization temperatures, implying different ease of cooking. Cassava starch has a lower cooking temperature, relatively to cereal starches; the pasting temperatures for cassava, corn, wheat and rice are $60-65,75-80,80-85$ and $73-75^{\circ} \mathrm{C}$ (Swinkels, 1998; Thirathumthavorn \& Charoenrein, 2005).

The starch hydrolysis by enzymes is a two-stage process involving liquefaction and saccharification. Liquefaction is a step that starch is degraded by an endo-acting enzyme namely $\alpha$-amylase, which hydrolyzes only $\alpha-1,4$ and causes dramatically drop in viscosity of cooked starch. Typically, liquefying enzymes can have an activity at a high temperature (> $85^{\circ} \mathrm{C}$ ) so that the enzyme can help reduce paste viscosity of starch during cooking. The dextrins, i.e. products obtained after liquefaction, is further hydrolzyed ultimately to glucose by glucoamylase enzyme which can hydrolyze both $\alpha-1,4$ and $\alpha-1,6$ glycosidic linkage. Glucose is then subsequentially converted to ethanol by yeast. By the end of fermentation, the obtained beer with approximately $10 \% \mathrm{v} / \mathrm{v}$ ethanol, depending on solid loading during fermentation, is subjected to distillation and dehydration to remove water and other impurities, yielding anhydrous ethanol (Figure 1).

\subsection{Cassava feedstock}

Cassava roots can be used as the feedstock for bioethanol production. During the harvest season, roots are plenty and cheap. However, roots contain very high moisture contents and 


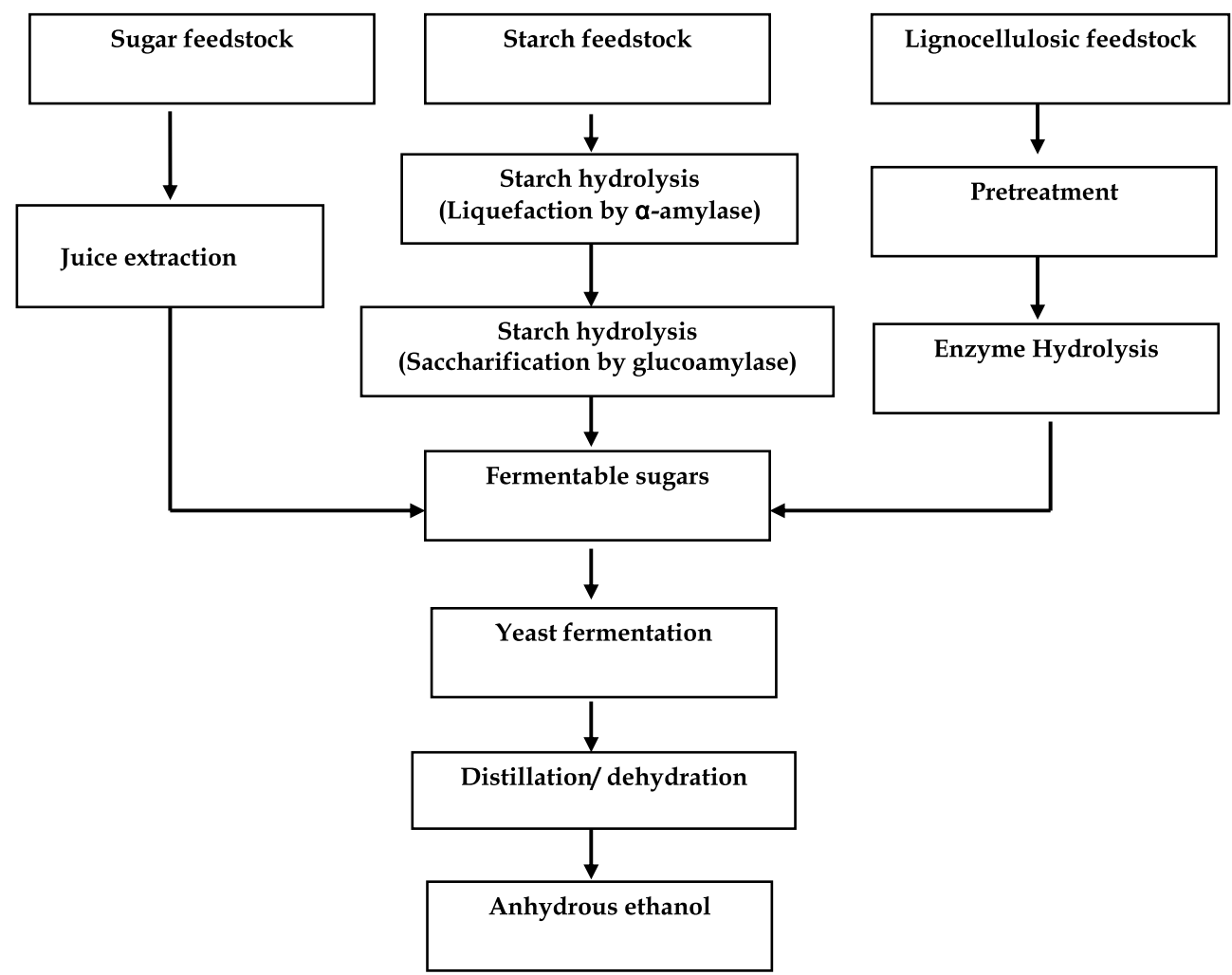

Fig. 1. Schematic diagram of bioethanol production by fermentation process of sugar, starch and lignocellulosic feedstock.

are prone to spoilage over the storage time. Mostly, roots are transformed readily to a dried form called cassava chips nearby the plantation areas. To produce chips, harvested roots are cut into pieces manually or by small machine and then sun-dried. The dried chips contain low moisture contents $(<14 \%)$, are less bulky, less costly for transportation and can be stored for a year in the warehouse. In addition, dried cassava chips have comparable characteristics as corn grains and can be processed by adopting conversion technology of corn grains. Cares must be taken when storing dried chips as heat can be generated and accumulated inside the heap. Therefore, the warehouse should have a good air ventilation system to prevent overheating and burning of chips. When used, the chips have to be transferred, using the rule of first-in and first-out, to the process line. Dusts are produced, resulting in starch loss as well as severe air pollution. The major concern of using chips is soil and sand contamination, being introduced from roots and during drying on the floor. Sand and soil can cause machine corrosion and result in shorter machine shelf life. They have to be removed in the production process. In Thailand where chips are used for many applications including animal feed and bioethanol production, farmers are encouraged to produce a premium quality of chips that meets with the standard regulation announced by Ministry of Commerce (Table 5). 


\begin{tabular}{|l|l|}
\hline \multicolumn{1}{|c|}{ Parameter } & \multicolumn{1}{c|}{ Value } \\
\hline Starch content & \\
\hline - by Polarimetric method & Not less than $70 \%$ by weight \\
\hline - by Nitrogen Free Extract, NFE & Not less than $75 \%$ by weight \\
\hline Fiber & Not greater than $4 \%$ by weight \\
\hline Moisture & Not greater than $13 \%$ by weight \\
\hline Sand and soil & Not greater than $2 \%$ by weight \\
\hline Unusual color and odor & Not detected \\
\hline Spoilage and molds & Not detected \\
\hline Living insects & Not detected \\
\hline
\end{tabular}

Table 5. Standard quality of premium grade of cassava chips, announced by Ministry of Commerce, Thailand.

When cassava is used for bioethanol production, different forms including fresh roots, chips and starch can be used. Table 6 summarizes advantages and disadvantages of using different forms of cassava feedstock. The factory has to make and manage an effective feedstock plan as the feedstock cost can account upto $70 \%$ of total ethanol production cost. Types of feedstock used for bioethanol plants depend on many concerns including plant production capacity, plant location, nearby cassava growing areas, amount of feedstock available and processing technology. Ethanol plants that are not close to cassava farms prefer to use dried chips to reduce costs of transportation and storage, while those locating next to cassava fields can use chips and roots. When using both feedstocks, the plants have to somewhat adjust the process in particular feedstock preparation.

\subsection{Cassava feedstock preparation}

\subsubsection{Cassava chip}

Similar to bioethanol production of corn grains, there are two processes for preparing cassava chips which are "Dry Milling" and "Wet Milling". In Dry Milling process (Figure 2), chips are transferred to the hopper and a metal and stone detector. The chips are then milled and sieved to obtain fine powders. Coarse powders are remilled. The fine powder having all components including fibers is slurried with water and proceeds to cooking and enzyme hydrolysis. The heat to cook slurry for liquefaction process is usually from direct steam instead of a jet cooker due to the difficulties of handling particles and contaminants in slurry. Owing to contamination of sand, conveyor system and grinding system require special treatment. Furthermore, after passing through syrup making process, an extra separation unit or hydrocyclone is required to remove sand and other impurities. The dry milling process is suitable for batch fermentation. Most of existing factories in China and some factories being installed in Thailand apply this dry milling process as it uses less equipment and investment (Sriroth \& Piyachomkwan, 2010b).

As corn grains are composed of many valuable components including protein, lipid and starch, wet milling process has been developed as a separation technique in order to fractionate starch and other high-valued products including corn gluten meal with high protein content, corn gluten feed and corn germ for oil extraction. The grains are initially 


\begin{tabular}{|c|c|c|}
\hline Form & Advantages & Disadvantages \\
\hline $\begin{array}{l}\text { Fresh } \\
\text { roots }\end{array}$ & $\begin{array}{l}\text { - Low cost during harvest } \\
\text { - Less costly to remove soil \& sand } \\
\text { - Contain fruit water having some } \\
\text { nutrients and minerals that are } \\
\text { advantageous to yeast fermentation }\end{array}$ & $\begin{array}{l}\text { - Not available for whole year, seasonally } \\
\text { harvested } \\
\text { - Bulky, costly to transport } \\
\text { - Cannot be stocked / short shelf-life due to } \\
\text { high moisture content/ high perishability } \\
\text { - Difficult to adjust total dry solid content in } \\
\text { a fermentor } \\
\text { - Limit total dry solid content for high solid } \\
\text { loading or very high gravity (VHG) } \\
\text { fermentation }\end{array}$ \\
\hline $\begin{array}{l}\text { Dried } \\
\text { Chips }\end{array}$ & $\begin{array}{l}\text { - Extended shelf-life } \\
\text { - Can be stored } \\
\text { - Less costly for transportation } \\
\text { - Can be processed by applying } \\
\text { conversion technology of corn } \\
\text { grains }\end{array}$ & $\begin{array}{l}\text { - Higher cost than fresh roots } \\
\text { - Must be dried before stored } \\
\text { - High soil \& sand contamination } \\
\text { - Limit total dry solid content for high solid } \\
\text { loading or very high gravity (VHG) } \\
\text { fermentation }\end{array}$ \\
\hline Starch & $\begin{array}{l}\text { - Less costly to stock } \\
\text { - Less costly to transport } \\
\text { - Easy to adjust total solid content in } \\
\text { a reactor and prepare high solid } \\
\text { loading slurry }\end{array}$ & $\begin{array}{l}\text { - High feedstock cost } \\
\text { - High production cost } \\
\text { - Loss of nutrients during starch extraction } \\
\text { process } \\
\text { - High demand in other production of } \\
\text { valued products }\end{array}$ \\
\hline
\end{tabular}

Table 6. Advantages and disadvantages of different forms of cassava feedstock.

cleaned and soaked in steeping water containing some chemicals such as sulfur dioxide, the most typically used one, and lactic acid to soften the grains. The soften kernels are milled to be suitable for degermination process and separated germ is used for oil extraction. Degermed ground kernels are then passed through fine mills so that the fiber can be readily separated. The protein is further fractionated from the defibered starch slurry by centrifugal separators. After fractionation of each component, starch slurry is further processed to cooking and enzyme hydrolysis for ethanol production. In wet milling process of cassava chips (Figure 3), the starch slurry is prepared from dried chips by modifying typical cassava starch production process. Unlike wet milling of corn grains with water, the chips are milled to fine powder before slurried with water. The process is sometimes named as "Starch milk" process of which the starch is then extracted from chips by a series of extractors. After depulping, the starch slurry is then concentrated by a separator and subjected to a jet cooker for liquefaction. Currently, only a few plants are using this process, because this process requires a high investment. Factories have modified the process by reducing the extractor and stipping tank unit. Wet milling generates high starch losses in the solid waste. However, the process is more controllable and can be practically applied to high solid loading and continuous fermentation process (Sriroth \& Piyachomkwan, 2010b).

In contrast to wet milling process, dry-milling process does not fractionate each component, yielding a by-product of mixed components. Although more valuable products are coproduced by wet milling process, this process is capital and energy intensive and results in a lower yield of ethanol as compared to dry-milling process; one ton of corn yields 373 and 388 liters of ethanol when processed by wet- and dry -milling, respectively (FO Licht, 2006). 


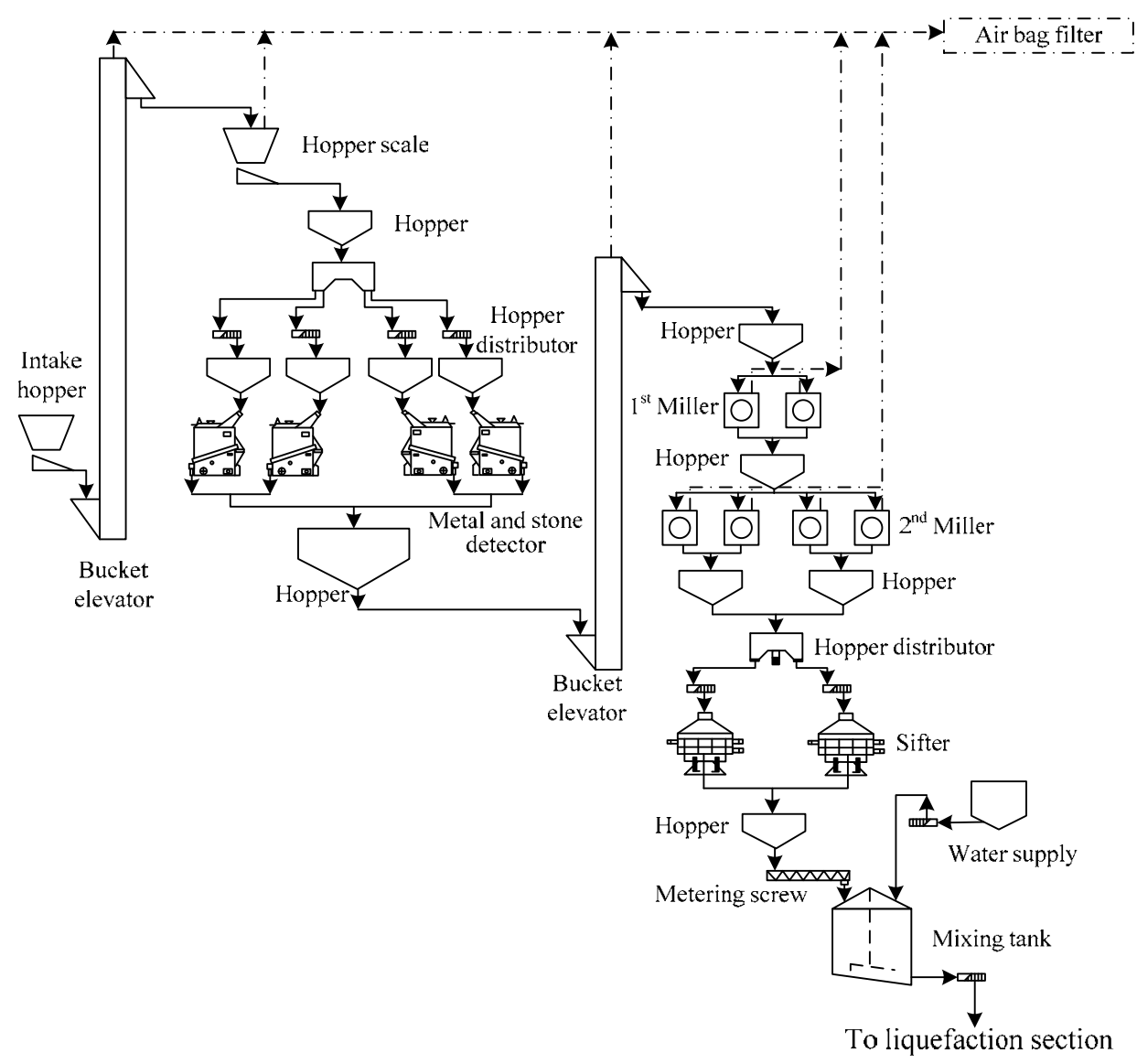

Fig. 2. "Dry milling" process for bioethanol production from dried cassava chips.

A modified dry-milling process has been developed recently by quickly removing germ or both germ and fiber prior to fermentation (Singh and Eckhoff, 1997; Wahjudi et al., 2000; Huang et al., 2008). This combined process improves cost reduction as compared to wetmilling process while increases value addition to dry-milling process. Although, cassava chips are corn analog and can be processed either by wet-milling or dry-milling process, the chips do not contain other valuable components. Dry-milling process is therefore generally applied for bioethanol production.

\subsubsection{Cassava roots}

During cassava harvest season, fresh roots are plenty available and the price is low. Therefore, it is common to use them to make slurry by grinding and then mix with cassava chip. Alternatively, cassava roots are used as a main raw material and then cassava chips are used to adjust the solid concentration. Similar to dried chips, there are two processes for preparing cassava fresh roots for bioethanol production, namely "With fiber" and "Defiber" process. 


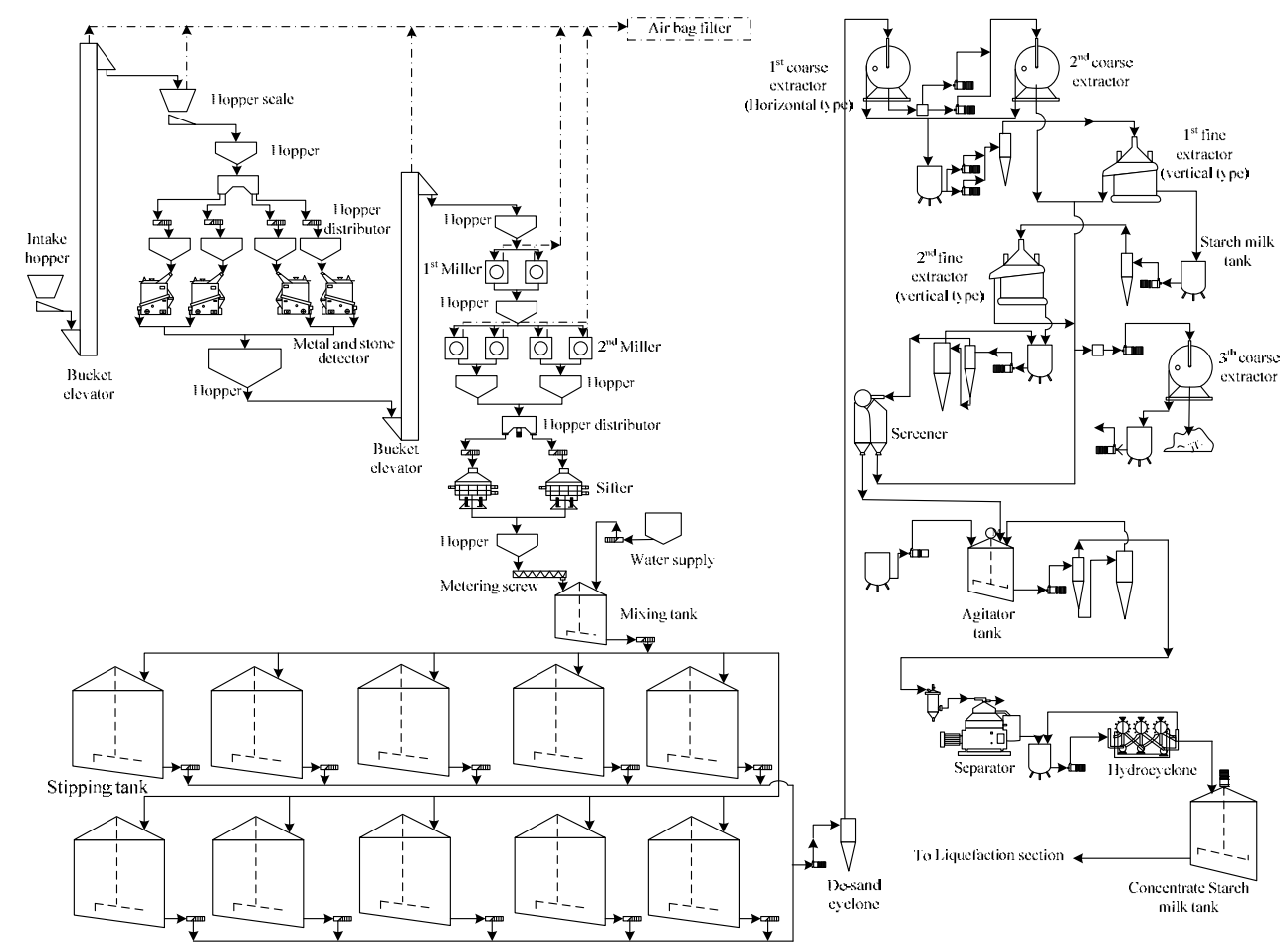

Fig. 3. "Wet milling" or "Starch Milk" process for bioethanol production from dried cassava chips.

In "With Fiber" process (Figure 4), the roots are transferred to the root hopper, in which soil and sand are effectively removed by root peelers. The roots are then washed and subjected to the chopper and rasper. The puree of milled roots is then slurried without fiber removal and used for liquefaction. This process requires less equipment and investment cost and is recommended for batch-type fermentation (Sriroth \& Piyachomkwan, 2010b). However, with the presence of cell wall materials, ground fresh roots has developed semi-solid like characteristic and should be slurried with water to reduce viscous behavior. This causes dilution of solid loading in a fermentor, yielding a low ethanol concentration in final beer. A pretreatment of ground fresh roots with appropriate cell wall degrading enzymes has been introduced to handle that inferior flowability (Martinez-Gutierrez et al., 2006; Piyachomkwan et al., 2008), allowing potential use of fresh roots with Very High Gravity (VHG), i.e. high solid loading (> 30\%) process and resulting in a higher ethanol concentration (upto $14.6 \% \mathrm{w} / \mathrm{w}$ or $18 \% \mathrm{v} / \mathrm{v}$ ) in beer (Thomas et al., 1996). By almost doubling the ethanol concentration in the final beer, the VHG process can not only minimize the energy consumed during the downstream distillation process, but also improve the plant capacity. This concept can be applied to improve fermentation of other feedstock as well.

Similar to wet milling process of cassava chips, in "De-fiber" process (Figure 5), the starch slurry is prepared from fresh roots by modifying a typical cassava starch production 


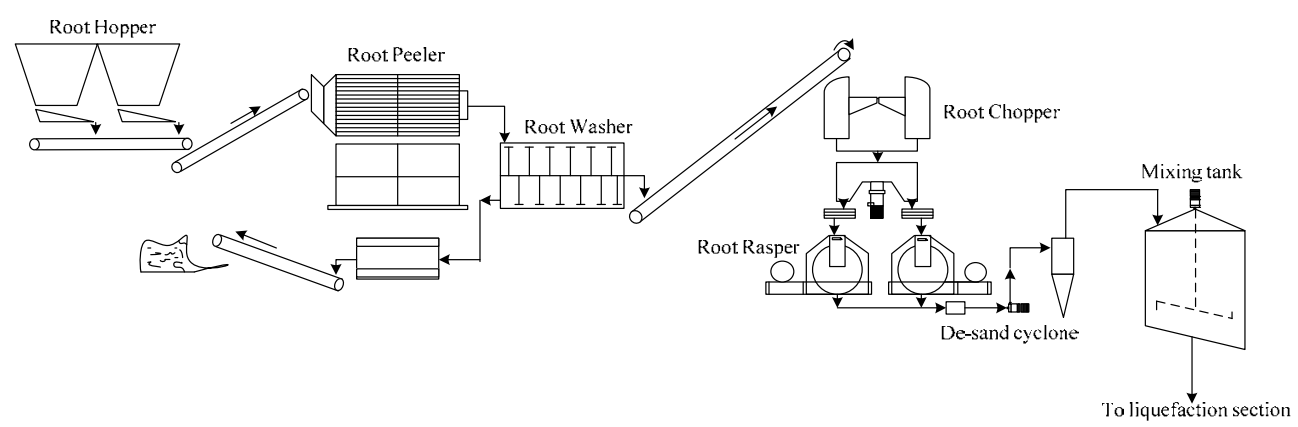

Fig. 4. "With fiber" process - starch slurry preparation from fresh cassava roots for bioethanol production.

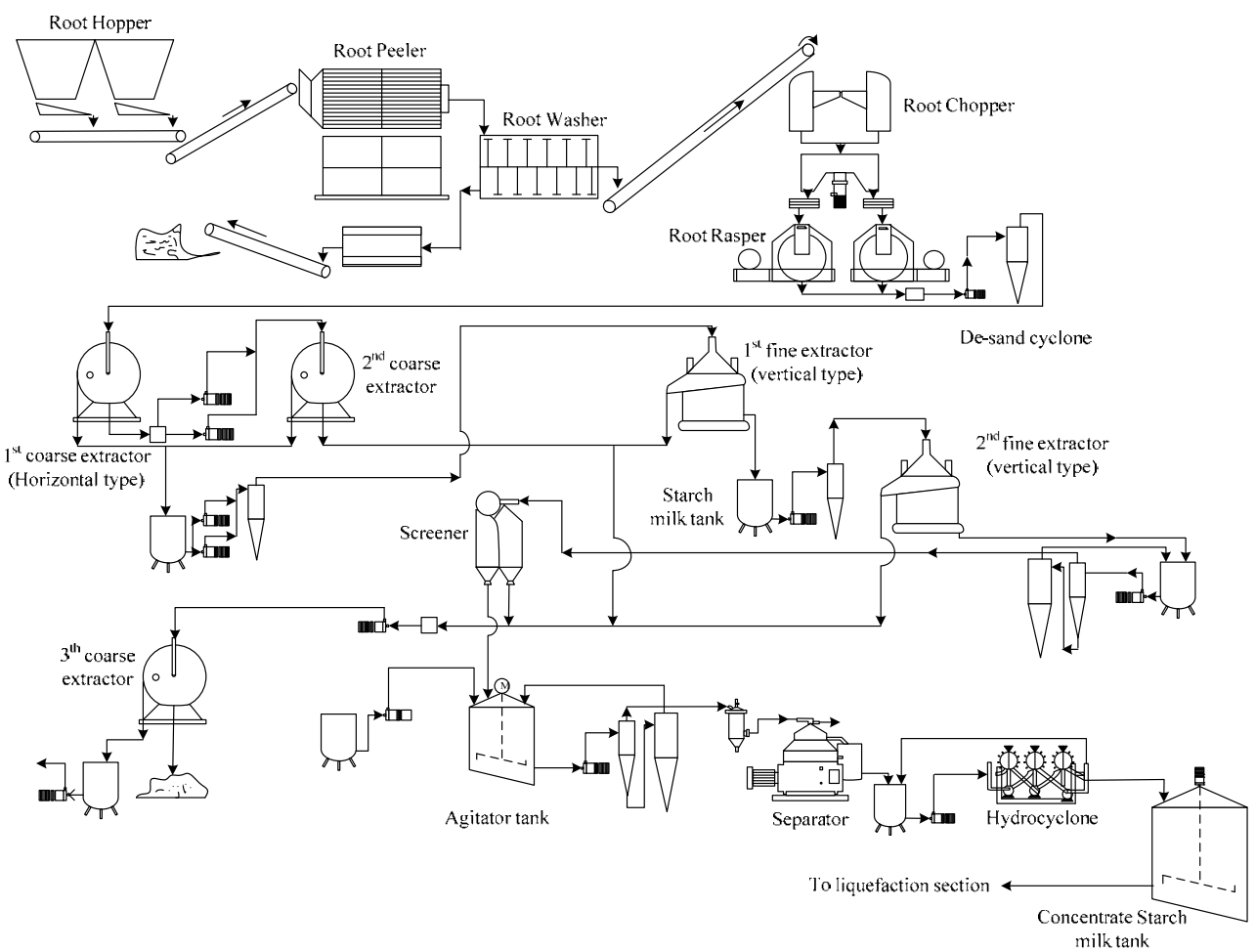

Fig. 5. "De-fiber" process - starch slurry preparation from fresh cassava roots.

process. After desanding and washing, roots are subjected to the chopper and rasper. The pulp is removed and starch is extracted by a series of extractors. After depulping, the starch slurry is then concentrated by a separator and subjected to a jet cooker for liquefaction. This process requires a higher investment cost and also generates high starch losses in the pulp. However, defiber process is more controllable and can be readily applied to current wellestablished technology of ethanol production from other materials. It is also practical for 
applying in high solid loading and continuous fermentation process (Sriroth \& Piyachomkwan, 2010b).

\subsection{Cassava bioethanol production}

As described previously, the ethanol production from cassava feedstock involves 5 main steps (Figure 6a) which are

- Feedstock preparation: the main purpose of this step is to make cassava feedstock be physically suitable for downstream processing, i.e. cooking, starch hydrolysis, fermentation and distillation \& dehydration. Details are different regarding to types of feedstock and milling process. In general, the preparation includes impurity removal (washing and peel removal of fresh roots, metal detector, sand and soil removal of slurry by hydrocyclone), size reduction by milling or rasping and fiber separation.

- Cooking: The starch is cooked to rupture the granular structure and hence improve its susceptibility to enzyme hydrolysis. Cooking is achieved at a temperature greater than a gelatinization temperature. During cooking, the high viscosity of the slurry is developed due to starch gelatinization and swelling of some particles. Cooking is, therefore, commonly performed in a presence of liquefying enzymes, i.e. $\alpha$-amylase to liquefy cooked slurry.

- Starch hydrolysis: Starch is enzymatically hydrolyzed to glucose by $\alpha$-amylase and subsequently by glucoamylase. The liquefaction by $\alpha$-amylase is usually conducted at high temperatures at which the starch become gelatinized. After liquefaction, the liquefied slurry is cooled down to an optimum temperature for glucoamylase hydrolysis which is about $50-55^{\circ} \mathrm{C}$, depending on enzyme types.

- Yeast fermentation: Glucose is then fermented by yeast. By the end of fermentation, the obtained beer contains approximately $10 \% \mathrm{v} / \mathrm{v}$ ethanol, depending on solid loading during fermentation.

- Distillation and dehydration: The beer is subjected to distillation to concentrate the ethanol to $95 \%$ and then dehydration to remove water, yielding anhydrous ethanol $(99.5 \%)$.

Nowadays, the production process of bioethanol from starch feedstock is developed to significantly reduce processing time and energy consumption by conducting saccharification and fermentation in a same step; this process is called "Simultaneous Saccharification Fermentation", or SSF process (Figure 6b). In this SSF process, the liquefied slurry is cooled down to $32^{\circ}$, afterward glucoamylase and yeast are added together. While glucoamylase produces glucose, yeast can use glucose to produce ethanol immediately. No glucose is accumulated throughout the fermentation period (Figure 7) (Rojanaridpiched et al, 2003).

The material balance of ethanol process with a production capacity of 150,000 liters/day, a recommended size of ethanol plants for optimum production costs, feasible feedstock management and effective waste water treatment, from dried cassava chips by Simultaneous Saccharification and Fermentation (SSF) process is estimated from production data collected during pilot trials (at 2,500 L working volume) and factory survey (Figure 8) (Sriroth et al., 2006). The conversion ratio of feedstock ( $\mathrm{kg}$ ) to ethanol (liter, L) is about 2.5:1 for dried chips or 6:1 for fresh roots, this conversion factors are starch-quantity dependent. Based on the pilot production data, the estimated production cost, excluding the feedstock cost, of ethanol from cassava chips by SSF process is about 0.259 USD/L (Rojanaridpiched et 
al., 2003; Sriroth et al., 2006) which is close to a value reported by FO Licht to be 0.24 USD/L (FO Licht, 2006). The estimated production cost of cassava chips are detailed in Table 7 (Sriroth et al., 2010a).
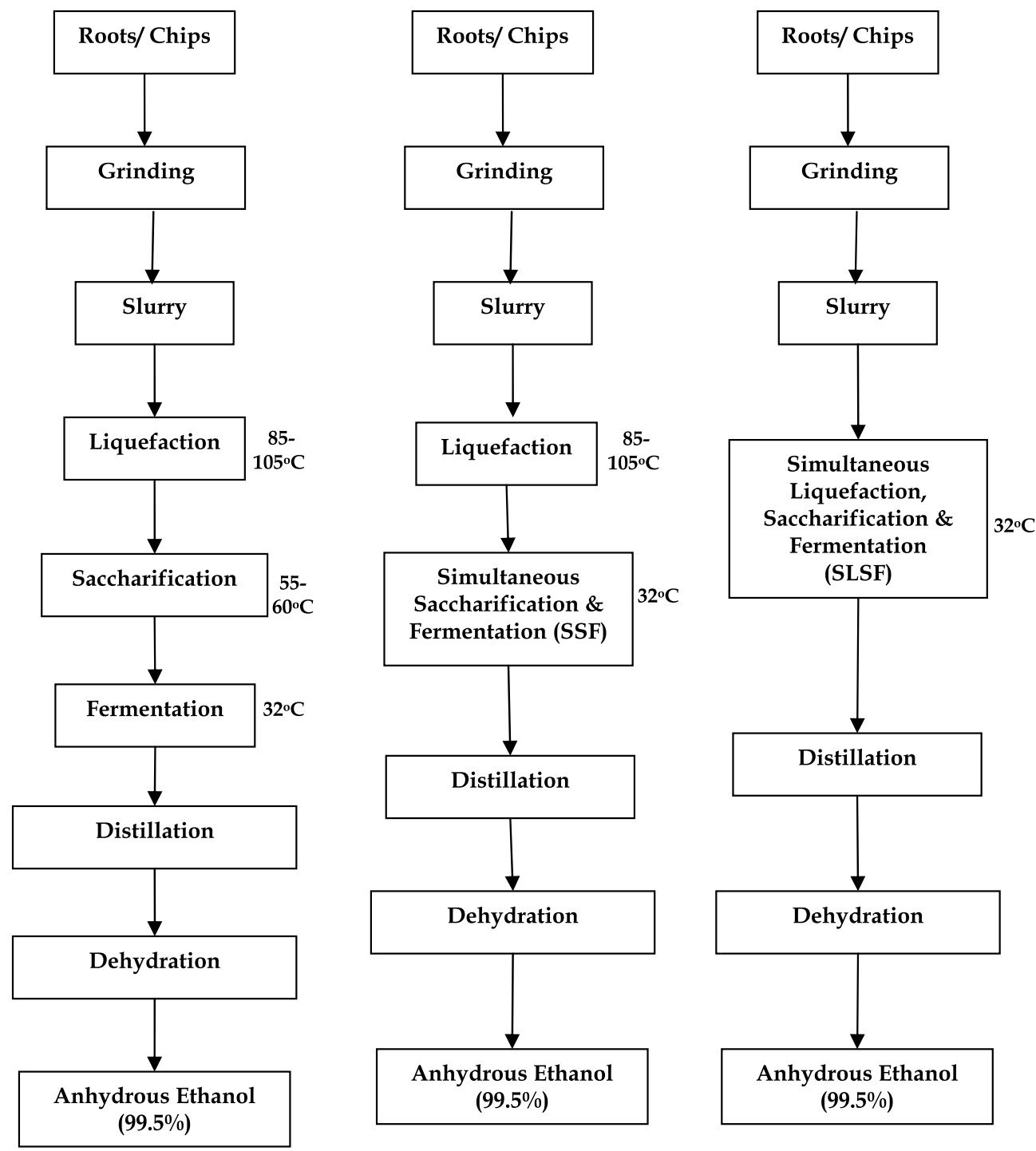

Note: The temperatures are enzyme- and yeast-type dependent.

Fig. 6. (a) Conventional, (b) SSF, Simultaneous Saccharification and Fermentation and (c) SLSF, Simultaneous Liquefaction, Saccharification and Fermentation process of ethanol production from cassava feedstock. 


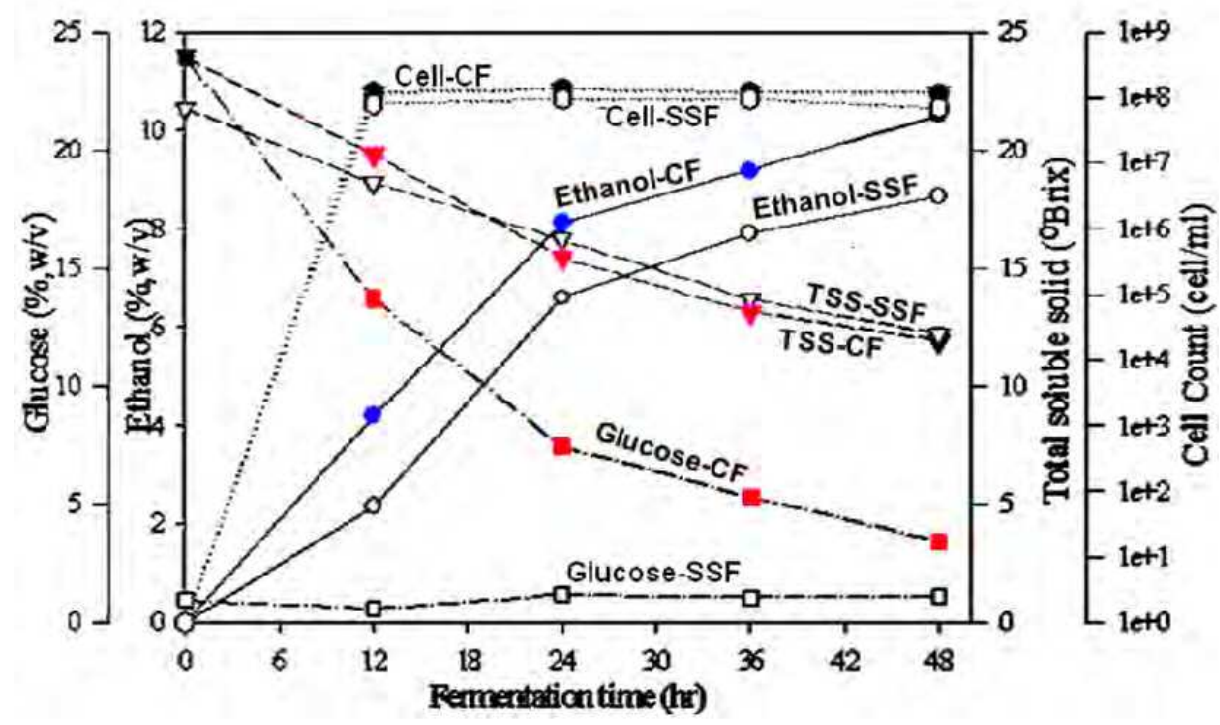

Fig. 7. Changes of total soluble solid (TSS, ${ }^{\circ}$ Brix by a refractometer), cell counts, glucose and ethanol contents (by High Performance Liquid Chromatography using Bio-Rad Aminex HPX-87H column), during ethanol fermentation from cassava chips by conventional fermentation (CF) and Simultaneous Saccharification and Fermentation (SSF) process. (Experimental condition for CF; a slurry of $25 \%$ dry solid was initially liquefied by $\alpha$ amylase at $95^{\circ} \mathrm{C}$, saccharified by glucoamylase at $60^{\circ} \mathrm{C}$ and then fermented by yeast (Saccharomyces cerevisiae) at $32^{\circ} \mathrm{C}$ ) and for SSF; a slurry of $25 \%$ dry solid was liquefied in a similar manner and then subjected to SSF by adding a mixture of glucoamylase enzyme and yeast at $32^{\circ} \mathrm{C}$ ).

In SSF process, the starch in cassava material has to be initially cooked and liquefied prior to SSF process. Recently, a granular starch hydrolyzing enzyme has been developed to produce fermentable sugars from native or uncooked corn starch and is then applied to cassava chips (Piyachomkwan et al., 2007; Sriroth et al., 2008). This enzyme can attack directly to uncooked starch granules (Figure 9), allowing liquefaction, saccharification and, in the presence of yeast, fermentation to occur simultaneously in one step at the ambient temperature without cooking; this process is Simultaneous Liquefaction, Saccharification Fermentation or SLSF (Figure 6c). Figure 10 demonstrates the ethanol production from cassava chips using conventional, SSF and SLSF process. It is interesting to note that by SLSF process, the total soluble solid and glucose content do not change over fermentation as starch is used in a native, granular insoluble form. The fermentation efficiency of SLSF process is reported to be comparable with cooked process (Table 8). SLSF process is energysaving, easy to operate and can be applied economically to produce sustainable energy, at a small scale, for community. 


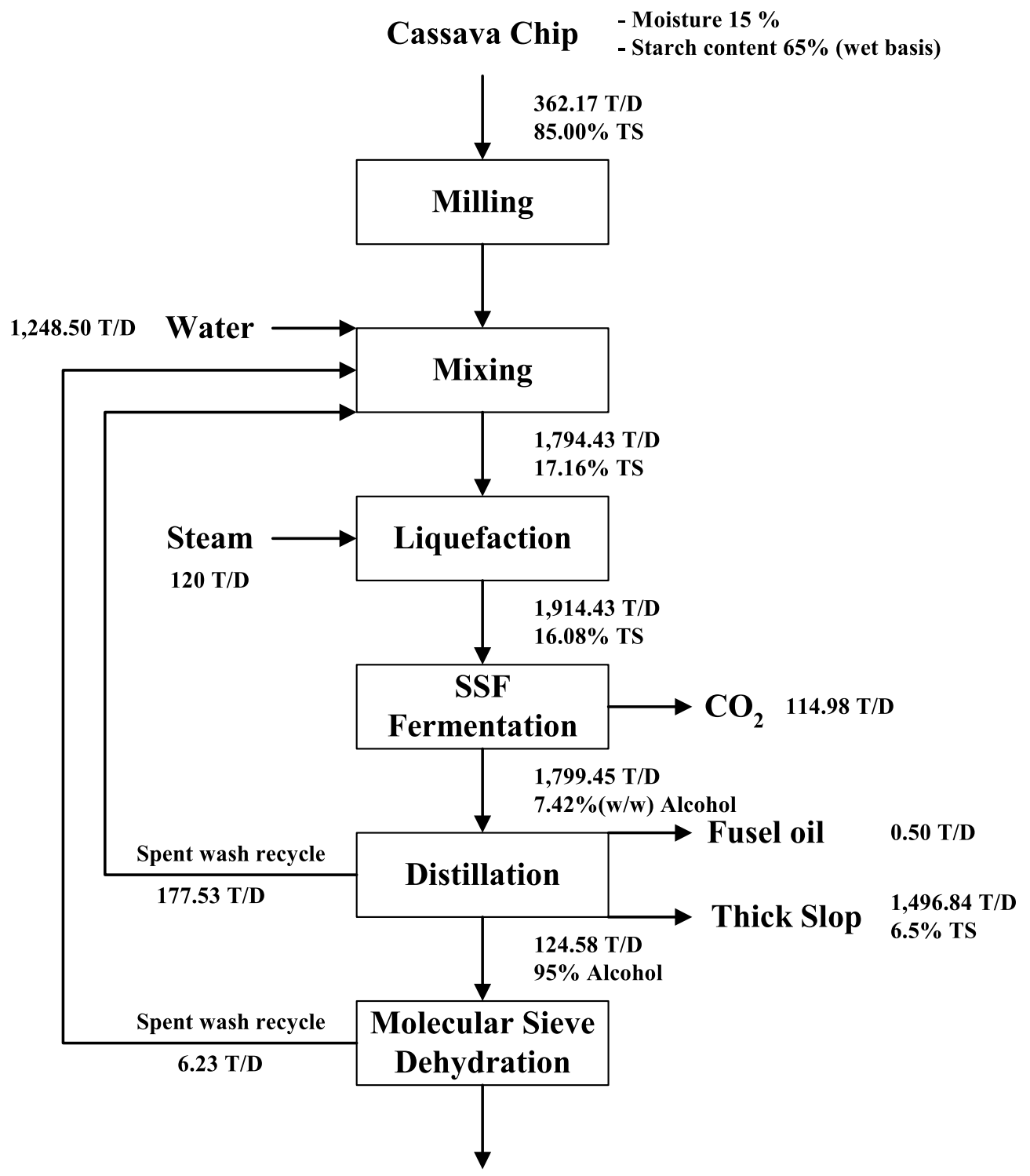

\section{Fuel Ethanol}

118.35 T/D or

$150,000 \mathrm{~L} / \mathrm{D}$

Fig. 8. Mass balance of ethanol production from cassava chip by SSF (Simultaneous Saccharification and Fermentation) process; T/D = Tons/Day, TS = Total Solid, L/D =Liter/day (Fermentation efficiency 90\%, Distillation efficiency 98.5\%) Source: Sriroth et al., 2006 


\begin{tabular}{lcc}
\hline \multirow{2}{*}{ Descriptive } & \multicolumn{2}{c}{ Estimated production costs (USD/L) } \\
\cline { 2 - 3 } & Thailand ${ }^{1}$ & China \\
\hline Materials and chemicals & $0.032^{\mathrm{b}}$ & $0.201^{\mathrm{c}}$ \\
Energy & 0.109 & 0.013 \\
Wage and addition & 0.014 & 0.005 \\
Depreciation & 0.036 & 0.016 \\
Maintenance & 0.002 & 0.011 \\
Miscellaneous & 0.007 & 0.003 \\
Fiscal charges & 0.029 & 0.013 \\
Land rent expense & - & 0.0003 \\
Selling expense & 0.014 & 0.003 \\
Waste treatment & 0.014 & - \\
Insurance & 0.002 & - \\
Water & - & - \\
\hline Total cost & 0.259 & 0.267 \\
\hline
\end{tabular}

1 the conversion ratio $=400 \mathrm{~L}$ ethanol $/$ ton of cassava chips and the material and chemical cost excludes the raw material cost.

${ }^{2}$ the conversion ratio $=460 \mathrm{~L}$ ethanol $/$ ton of cassava chips and the material and chemical cost includes raw material cost.

Source: Sriroth et al., 2010a

Table 7. Estimated production costs of ethanol from cassava chips by Simultaneous Saccharification and Fermentation (SSF) process.

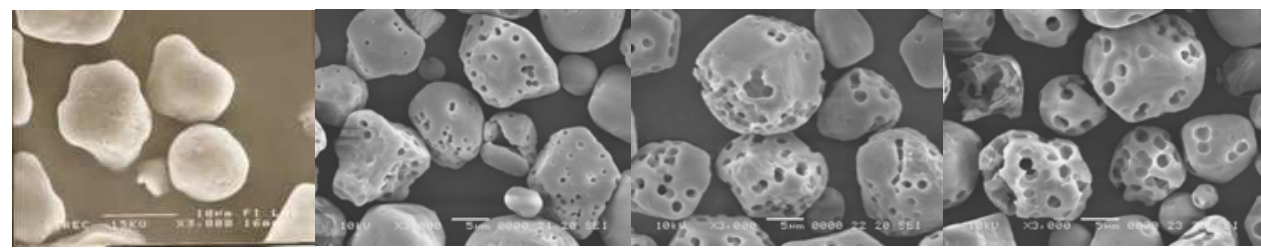

Corn starch

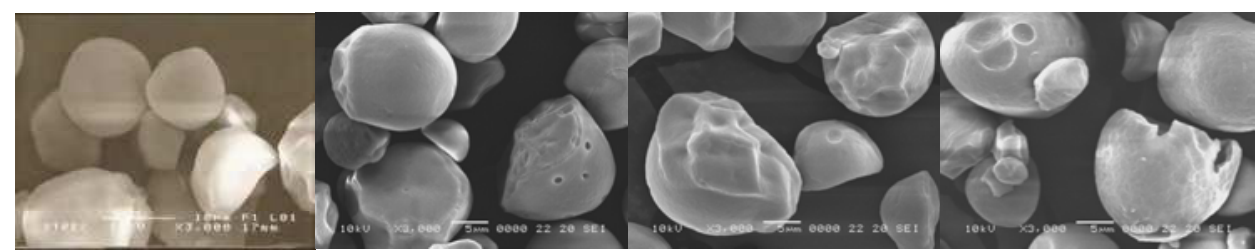

Cassava starch
$\mathrm{O} \mathrm{hr}$
$12 \mathrm{hr}$
$24 \mathrm{hr}$
$48 \mathrm{hr}$

Fig. 9. Scanning electron microscopic (SEM, at 3,000x magnification) pictures of corn and cassava starches treated with granular starch hydrolyzing (using $30 \% \mathrm{db}$ starch in $0.05 \mathrm{M}$ acetate buffer, $\mathrm{pH} 4.5$ and incubating with $0.5 \%$ granular starch hydrolyzing enzyme (Stargen ${ }^{\mathrm{TM}}$, Danisco-Genencor, USA, at $32^{\circ} \mathrm{C}$ ).

Source: Sriroth et al., 2007 


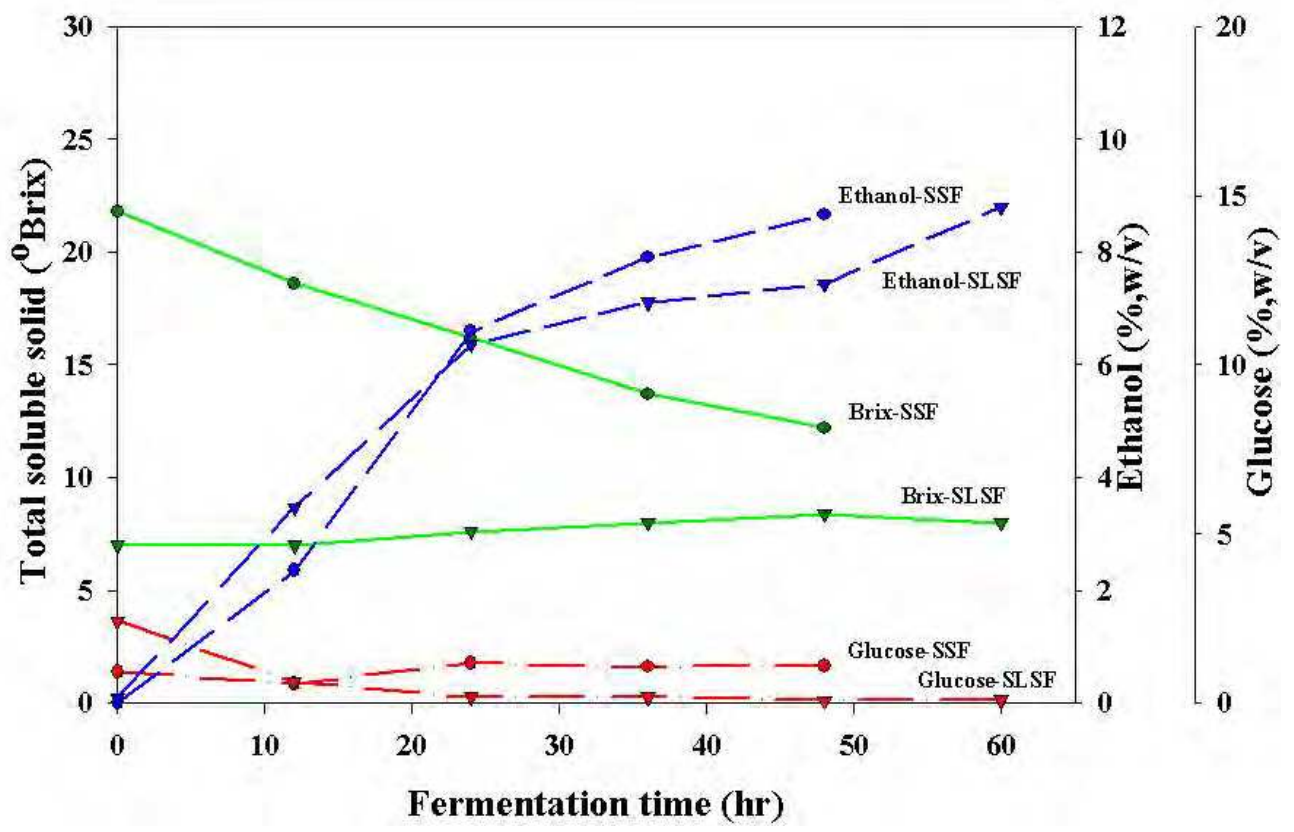

Fig. 10. Changes in total soluble solids ( ${ }^{\circ}$ Brix), glucose and ethanol content $(\% \mathrm{w} / \mathrm{v})$ during ethanol production from cassava chips by Simultaneous Saccharification and Fermentation (SSF; the slurry of $25 \%$ dry solid was liquefied by $0.1 \%$ Termamyl $120 \mathrm{~L}$ (Novozymes) at 95$100^{\circ} \mathrm{C}, 2 \mathrm{hr}$ followed by simultaneous saccharification and fermentation with $0.1 \%$ AMG (Novozymes) and Saccharomyces cirivisiae yeast at $32^{\circ} \mathrm{C}$ for $48 \mathrm{hrs}$ ) and Simultaneous Liquefaction, Saccharification and Fermentation (SLSF; the slurry of $25 \%$ dry solid was liquefied, saccharified and fermented with $0.25 \%$ granular starch hydrolyzing enzyme (Stargen ${ }^{\mathrm{TM}}$, Danisco-Genencor, USA) and Saccharomyces cirivisiae yeast at $32^{\circ} \mathrm{C}, 60 \mathrm{hr}$. Source: Rojanaridpiched et al., 2003 ; Sriroth et al., 2007

\subsection{Cassava bioethanol wastes and their utilization}

During cassava bioethanol production, wastes are generated; the quantity and quality are depending significantly on feedstock quality and processing types. Since dry milling process is more widely used for bioethanol production from cassava feedstock, the information provided here is based on dry milling process of cassava chips. Similar to dry milling process for bioethanol production of corn grains, both of solid and liquid wastes are obtained at the end of distillation. The waste can be generated as a whole stillage containing both solid and liquid waste if the whole beer is subjected to the mash column without fiber separation. This process is applied in order to minimize ethanol loss in the solid pulp if fiber separation is accomplished prior to distillation. Recently, the process is adjusted by separating the fiber first and the fiber is washed to collect ethanol in pulp. At the production capacity of 150,000 liters of anhydrous ethanol/day, the total whole stillage is produced approximately 1,400-1,600 $\mathrm{m}^{3}$ /day, being wet cake 100-200 ton/day and the stillages 1,200$1,400 \mathrm{~m}^{3} /$ day (Sriroth et al., 2006). 


\begin{tabular}{|l|c|c|}
\hline \multirow{2}{*}{\multicolumn{1}{|c|}{ Parameters }} & \multicolumn{2}{|c|}{ Values } \\
\cline { 2 - 3 } & SSF $^{2}$ & SLSF $^{2}$ \\
\hline Slurry & & \\
Volume (L) & 2,053 & 2,200 \\
\% Total solid (w/v) & 24.18 & 24.24 \\
\% Starch content of chips & $80.4 \%$ & $74.49 \%$ \\
pH & 4.68 & 4.45 \\
\hline Beer after fermentation & & \\
Fermentation time (hrs) & 48 & 60 \\
Volume (L) & 2,166 & 2,258 \\
Total soluble solid (oBrix) & 12.2 & 7.4 \\
Glucose content (\%w/v) & 1.09 & 1.24 \\
Ethanol content (\%w/v) & 8.66 & 8.18 \\
Cell counts (x 107 cell/ml) & 6.82 & 1.15 \\
\hline Yield & & \\
g ethanol/g dried chips & 0.378 & 0.344 \\
g ethanol/g starch & 0.470 & 0.462 \\
\%Fermentation efficiency 3 & 82.88 & 82.11 \\
\hline
\end{tabular}

${ }^{1}$ Using $25 \%$ dry solid of chips, liquefied by $0.1 \%$ Termamyl $120 \mathrm{~L}$ (Novozymes) at $95-100^{\circ} \mathrm{C}, 2 \mathrm{hr}$ followed by simultaneous saccharification and fermentation with $0.1 \%$ Rhizozyme (Alltech) or AMG (Novozymes) and Saccharomyces cirivisiae at $32^{\circ} \mathrm{C}$ for $48 \mathrm{hrs}$.

2 Using $25 \%$ dry solid of chips, liquefied, saccharified and fermented with $0.25 \%$ granular starch hydrolyzing enzyme (Stargen ${ }^{\mathrm{TM}}$, Danisco-Genencor, USA) and Saccharomyces cirivisiae at $32^{\circ} \mathrm{C}, 60 \mathrm{hr}$.

${ }^{3}$ as a percentage of theoretical yield

Source: Rojanaridpiched et al., 2003 ; Sriroth et al., 2007

Table 8. Parameters and results of ethanol production from cassava chips by SSF and SLSF process.

\subsubsection{Solid waste}

The wet cake has the total solid around $20-30 \%$ and contains a mixed component of cassava feedstock since no fractionation of cassava components is employed in dry milling process. The wet cake can be used to produce Dry Distillers Grains With Solubles or DDGS as developed in corn ethanol industry. However, cassava roots do not contain a high protein content as corn grains, cassava DDGS contains less protein contents (around $11-14 \%$ and $30 \%$ dry basis for cassava and corn DDGS; Sriroth et al., 2006). Though the solid waste from cassava chips is not as valuable as corn DDGS, it can be utilized in many ways:

- To produce biogas: this waste treatment has been practiced in China. The solid waste in the thick slop is sent to Biomethylation process. The results are successfully reported by Dai et al. (2006).

- To feed the burner: Another alternative design for Thai factories is that the solid waste from the thick slop is separated by a decanter so that the moisture content is around $50 \%$ of total solids $\left(50 \% \mathrm{H}_{2} \mathrm{O}\right)$. This semi-dry solid is then used as the feedstock for fuel production by direct burning.

- $\quad$ To supplement in animal feed: The solid waste contains some fibers, proteins and ash and can be used as animal feed fillers. 


\subsubsection{Liquid waste (stillage)}

Whilst the slop from molasses is very dark in color, cassava liquid waste has a light yellowish color with a lower COD $(40,000-60,000)$ and BOD $(15,000-30,000)$ values. The characteristics of waste water from the ethanol factories using cassava and molasses as feedstock are shown in Table 9. In consideration of this, the waste water from cassava-based process is much easier to handle than the waste obtained from molasses. This implies less investment and operational costs. In China, cogeneration of biogas obtained from waste water treatment in ethanol factory operating with cassava is reported to be able to cover all electricity needs in ethanol production process and still have some excess to supply to the grid (Dai et al., 2006). The practice for using thin stillage in Thailand is also for biogas production.

\begin{tabular}{|l|c|c|}
\hline \multicolumn{1}{|c|}{ Characteristic } & $\begin{array}{c}\text { Factory using cassava } \\
\text { chips }\end{array}$ & $\begin{array}{c}\text { Factory using } \\
\text { molasses }\end{array}$ \\
\hline $\begin{array}{l}\text { 1. Chemical Oxygen Demand (COD, } \\
\text { mg/L) }\end{array}$ & $40,000-60,000$ & $100,000-150,000$ \\
2. Biological Oxygen Demand (BOD, & $15,000-30,000$ & $40,000-70,000$ \\
mg/L) & $350-400$ & $1,500-2,000$ \\
3. Total Kjedahl Nitrogen (TKN, mg/L) & $60,000-65,000$ & $100,000-120,000$ \\
4. Total Solids (mg/L) & $3,000-20,000$ & $14,000-18,000$ \\
5. Total Suspended Solid (TSS, mg/L) & $20,000-40,000$ & n.a. \\
6. Total Volatile Solids (mg/L) & 50,000 & $105,000-300,000$ \\
7. Total Dissolved Solids (mg/L) & $3.5-4.3$ & $4.1-4.6$ \\
8. pH & \multicolumn{2}{|c}{} \\
\hline
\end{tabular}

Source: Sriroth et al., 2006; n.a. = not applicable

Table 9. Characteristics of stillage obtained from ethanol factories in Thailand.

\section{Lesson learned from Thai cassava bioethanol industry}

The ethanol industry in Thailand has been active since 1961 as one of the Royal Project of His Majesty the King. Later, as an oil-importing country, Thailand has lost economic growth opportunity and energy security due to limited oil supply and price fluctuation. The seek for alternative energy for liquid fuel uses for transportation sector has been developed as a part of National Energy Policy and ethanol was then upgraded as national policy in 1995, initially in order to replace a toxic Octane Booster, i.e. Methyl tert-butyl ether (MTBE) in gasoline. By that time, the consumption rate of gasoline was 20 million liters per day which required 10\% Octane Booster or 2 million liter per day; this formula is equivalent to Gasohol E10 (for octane 91 and 95), a blend of unleaded gasoline with 10\% v/v anhydrous ethanol. With a rising concern of Global Warming and Clean Development Mechanism (CDM), gasohol containing higher ethanol components has been currently developed; E20 \& E85. Presently, there are 47 factories legally licensed to produce biofuel ethanol with a total capacity of 12.295 million liters/day or 3,688.5 million liters per annum (at 300 working days). Two feedstocks, namely sugar cane molasses and cassava are their primary raw materials. A total of 40 factories use only a single feedstock; 14 factories using molasses with a total production capacity of 2.485 million liters/day, 25 factories using cassava with a total production capacity of 8.590 million liters/ day and 1 factory using sugar cane with a total 
production capacity of 0.2 million liters/ day. A multi-feedstock process using both molasses and cassava is, however, preferred in some factories ( 7 factories with a total production capacity of 1.020 million liters/day) to avoid feedstock shortage (Department of Alternative Energy Development and Efficiency, DEDE, 2009). A complication of Thai bioethanol industry is generated due to the fact that there are two feedstock types being used in other industries and also other alternative energy for transportation, i.e. LPG (Liquefied petroleum gas) and CNG (Compressed natural gas), being promoted by the government.

\subsection{Feedstock supply}

In Thailand, cassava is considered as one of the most important economic crops with the annual production around 25-30 million tons. The role of cassava in Thailand is not only as a subsistent cash crop of farmers, but it also serves as an industrial crop for the production of chips and starch, being supplied for food, feed and other products. This can be indicated by a continuous increase in root production since 2000 and be greater than 20 million tons since 2006. With the national policy on bioethanol use as liquid fuel, it significantly drives a rise in root demand. Various scenarios have been proposed to balance root supply and demand, in order to reduce the conflict on food vs. fuel security. Under the normal circumstance, root surplus should be used for bioethanol production, which initiates another industrial demand of roots and helps stabilize root price for farmers. Figure 11 is an example of projecting plan for root consumption by various industries, which corresponds to the targeted root production, proposed by Ministry of Agriculture and current root demand for chip and starch production. Another scenario is to reduce the amount of exporting chips and allocate those locally to existing industries. Meanwhile, the campaign for increasing root productivity (ton per unit area) by transferring good farming and agricultural practices has been distributed throughout the countrywide. In spite of that root shortage occurs in the last few years, caused by unexpected climatic change and widespread disease, i.e. mealy bugs. This, in fact, critically affects starch industries at a much greater extent than ethanol industry. Nevertheless, the starch industry is more competitive for higher root prices than ethanol industry. This situation of an unusual reduction of root supply emphasizes the need of increasing root production. A short-term policy on increasing root productivity from 25 tons/hectare by good farm management and cultivation practice has continuously pursued and expected to be 50 tons/hectare. Furthermore, long-term plan on R\&D for varietal improvement is also greatly significant in order to develop varieties with higher root productivity (potentially be upto 80 tons/hectare), good disease resistance and good adaptation to climatic change such as higher growing temperatures or very dry condition.

\subsection{Ethanol demand in biofuel use}

Presently, there are 17 factories operating with the total production capacity of 2.575 million liters/day but most of them have operated under their full production capacity due to oversupply of ethanol. The influencing factor for decreasing ethanol demand is other alternative energy for transportation, i.e. Liquid Petroleum Gas (LPG) and Compressed Natural Gas (CNG), being promoted by the government. LPG is a primary fuel for household use such as for cooking that is why it is important to control the price of LPG (being low at 18 Baht per kilogram or 0.59 USD per kilogram). This promotes an increase usage of LPG in automobile sector, as indicated by increasing automobile engine change from gasoline to LPG. For CNG, there are several policies being released to promote the use 


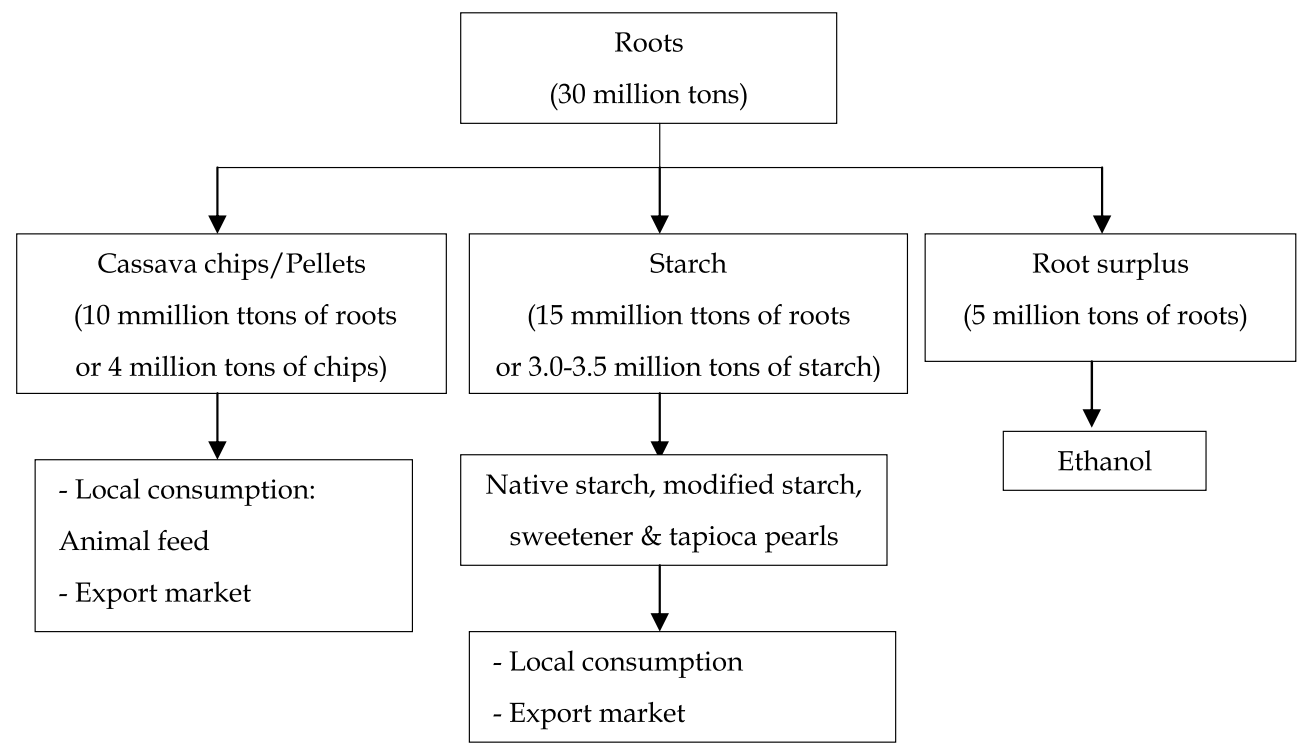

Fig. 11. Schematic diagram of cassava root consumption projection plan in Thailand.

of CNG in automobile sector in order to reduce the amount of gasoline consumption. Firstly, there is an exemption of tax for CNG fuel tank. Secondly, government agrees to cover the cost of changing car engine to CNG-using engine for taxi countrywide and tax reduction for CNG fuel cost. With the cost of production and fuel itself, the actual price is at 14.75 Baht per kilogram but the selling price is only at 8.50 Baht per kilogram. This difference requires a significant amount of subsidized oil fund to compensate the gap. At present, the government led by Ministry of Energy, has considered different mechanisms to intensify ethanol demands in transportation sector by promoting use of gasohol with a higher ethanol component (E85 and E100) for Flexible Fuel Vehicle (FFV), use of ethanol in motorbikes and use of ethanol as diesohol for trucks. These applications need technical support to acquire consumer's confidence. In addition, supporting policy and effective mechanism for exporting bioethanol can help expand market demand.

\subsection{Regulation and pricing}

To establish the local market for bioethanol demand in transportation sector, Thailand has released the regulation of denatured ethanol for gasohol uses (Table 10) to ensure high quality fuel for automobile use. No regulation for biofuel uses is announced by the government. In stead, the utilization of bioethanol as liquid fuel has been promoted by price incentive system. The retail price of gasohol E10 (for octane 95) is cheaper than gasoline around $0.33 \mathrm{USD} /$ liter by exemption and reduction of excise \& municipal tax and Oil Fund charge.

At the initial phase of trading ethanol locally, the price of ethanol for domestic market is referred to the price of imported ethanol from Brazil (FOB price of Brazilian Commodity Exchange Sao Paulo) with the additional cost of freight, insurance, loss, survey and currency exchange rate. Thai cassava ethanol industry has used two feedstock, i.e. molasses and cassava; the former one being utilized at a higher production capacity. This leads to shortage 


\begin{tabular}{|c|c|c|c|}
\hline No. & Description/Details & Value & Analytical method \\
\hline 1 & $\begin{array}{l}\text { Ethanol plus higher saturated } \\
\text { alcohols, \% vol. }\end{array}$ & $>99.0$ & $\begin{array}{l}\text { EN } 2870 \text { Appendix } 2 \\
\text { Method B }\end{array}$ \\
\hline 2 & $\begin{array}{l}\text { Higher saturated (C3-C5) } \\
\text { mono alcohols, \% vol. }\end{array}$ & $<2.0$ & EN 2870 Method III \\
\hline 3 & Methanol, \%vol. & $<0.5$ & $\begin{array}{l}\text { EN } 2870 \\
\text { Method III }\end{array}$ \\
\hline 4 & $\begin{array}{l}\text { Solvent washed gum, } \mathrm{mg} / 100 \\
\mathrm{~mL}\end{array}$ & $<5.0$ & ASTM D 381 \\
\hline 5 & Water, \%wt. & $<0.3$ & ASTM E 203 \\
\hline 6 & Inorganic chloride, $\mathrm{mg} / \mathrm{L}$ & $<20$ & ASTM D 512 \\
\hline 7 & Copper, mg/kg & $<0.07$ & ASTM D 1688 \\
\hline 8 & Acidity as acetic acid, mg/L & $<30$ & ASTM D 1613 \\
\hline 9 & $\mathrm{pH}$ & $>6.5$ and $<9.0$ & ASTM D 6423 \\
\hline 10 & Electrical conductivity, $\mu \mathrm{S} / \mathrm{m}$ & $<500$ & ASTM D 1125 \\
\hline 11 & Appearance & \multicolumn{2}{|c|}{$\begin{array}{l}\text { Clear liquid, not cloudy, homogenous, and no } \\
\text { colloidal particles }\end{array}$} \\
\hline 12 & Additive (if contains) & \multicolumn{2}{|c|}{$\begin{array}{l}\text { Agree with consideration of Department of } \\
\text { Energy Business }\end{array}$} \\
\hline
\end{tabular}

Source: Modified from Department of Energy Business, Ministry of Energy, Thailand (2005).

Table 10. The Thai standard of denatured ethanol for gasohol use as announced by the Department of Energy Business.

of molasses and price increase. As a result, the reference price based on Sao Paulo does not reflect the real ethanol situation of the country, both in term of production and uses. Subsequently, the pricing formula of biofuel ethanol has been revised. The reference price of bioethanol for fuel uses, as approved by The National Energy Policy Committee, Ministry of Energy, has taken into account for the cost of raw materials and produced quantities of fuel ethanol from both feedstocks, i.e. molasses and cassava, using the conversion ratios of 4.17 $\mathrm{kg}$ molasses (at $50^{\circ}$ Brix) and $2.63 \mathrm{~kg}$ cassava chips (with starch content $>65 \%$ ) for $1 \mathrm{~L}$ of anhydrous ethanol. In addition, the structure of ethanol reference prices includes the production costs of each feedstock, which are 6.125 and 7.107 Baht/L for molasses and cassava, respectively. This monthly-announced ethanol reference price reflects the actual cost of local ethanol producers.

$$
P_{\text {Eth }}=\frac{\left(P_{\text {Mol }} \times Q_{\mathrm{Mol}}\right)+\left(P_{\text {Cas }} \times Q_{\text {Cas }}\right)}{Q_{\text {Total }}}
$$

Where

$\mathrm{P}_{\text {Eth }}=$ Monthly reference price of ethanol (Baht/L)

$\mathrm{P}_{\mathrm{Mol}}=$ Price of molasses-based ethanol (Baht/L)

$\mathrm{P}_{\text {Cas }}=$ Price of cassava-based ethanol (Baht/L)

$\mathrm{Q}_{\mathrm{Mol}}=$ Quantity of molasses-based ethanol (million L/day) 
$\mathrm{Q}_{\text {Cas }}=$ Quantity of cassava-based ethanol (million L/day)

$\mathrm{Q}_{\text {Total }}=$ Total ethanol quantity (million L/day)

(For $\mathrm{Q}_{\mathrm{Mol}}, \mathrm{Q}_{\mathrm{Cas}}$ and $\mathrm{Q}_{\mathrm{Total}} \mathrm{using}$ the value of one month previously, e.g. for the $5^{\text {th }}$ month reference price, use the value of $3^{\text {th }}$ month)

$$
\mathrm{P}_{\mathrm{Mol}}=\mathrm{R}_{\mathrm{Mol}}+\mathrm{C}_{\mathrm{Mol}}
$$

Where

$\mathrm{P}_{\mathrm{Mol}}=$ Price of molasses-based ethanol (Baht/L)

$\mathrm{R}_{\mathrm{Mol}}=$ Raw material cost of molasses, using a previous 3-month average export price announced by Thai Customs Department and the conversion ratios of $4.17 \mathrm{~kg}$ molasses (at $50^{\circ}$ Brix) for $1 \mathrm{~L}$ of anhydrous ethanol, e.g. using the average export price of $1^{\text {st }}, 2^{\text {nd }}$, and $3^{\text {rd }}$ month to calculate the price of $5^{\text {th }}$ month

$\mathrm{C}_{\mathrm{Mol}}=$ Production cost of molasses-based ethanol (6.125 Baht/L)

$$
\mathrm{P}_{\text {Cas }}=\mathrm{R}_{\mathrm{Cas}}+\mathrm{C}_{\mathrm{Cas}}
$$

Where

$\mathrm{P}_{\text {Cas }}=$ Price of cassava-based ethanol (Baht/L)

$\mathrm{R}_{\text {Cas }}=$ Raw material cost of cassava, using the root price of one month previously, the conversion of $2.38 \mathrm{~kg}$ ( $25 \%$ starch) fresh roots for $1 \mathrm{~kg}$ of chips with the production cost of $300 \mathrm{Baht} / \mathrm{ton}$ chips, and the conversion ratios of $2.63 \mathrm{~kg}$ cassava chips (with starch content $>65 \%$ ) for $1 \mathrm{~L}$ of anhydrous ethanol

$\mathrm{C}_{\text {Cas }}=$ Production cost of cassava-based ethanol (7.107 Baht/L)

(Note: 1 USD = 30 Baht)

\section{Conclusion}

Cassava is not only a traditional subsistence food crop in many developing countries, it is also considered as an industrial crop, serving as a significant raw material base for a plenitude of processed products. Important ones are starches, modified starches and sweeteners for application in food, feed, paper, textile, adhesive, cosmetics, pharmaceutical, building and biomaterial. Consequently, the demand of cassava has been rising continuously and thereby contributes to agricultural transformation and economic growth in developing countries. Recently, in some countries such as Thailand, China and Vietnam, cassava is also used as the energy crop for producing bioethanol, an environmentally friendly, renewable alternative fuel for automobile uses. The promise of using cassava for bioethanol use is supported by many reasons including distinct plant agronomic traits for high tolerance to drought and soil infertility, low input requirement relatively to other commercial crop, and potential improvement of root yields. In addition, roots are rich in starch and contain low impurities. Although, fresh roots contain high moisture contents and are perishable, simple conversion to dried chip can be achieved by farmers at a low cost. Chips as corn analog are less costly to transport, store and process. High energy input for ethanol production from starch materials become less concerned as low energy consumption processes are developed including SSF, SLSF for uncooked process and VHG for a higher ethanol concentration. Improved waste treatment and utilization is also significant in order to minimize overall production cost. With those 
development, the use of cassava as an energy crop raises more concerns for food and fuel security. Both are critical to agricultural countries that mainly import fossil oil fuel and have lost their economic growth. To overcome that concern, the development of sufficient feedstock supply is considered as the first priority. A short-term and long term plans for root yield and productivity improvement by good cultivation practice and varietal improvement have been presently implemented in some regions. By that with a combination of zero-waste process concept, effective policies and market mechanism, the use of cassava as a food crop, industrial crop and energy crop become sustainable and beneficial to mankind.

\section{References}

Asaoka, M., Blanshard, J. M. V. \& Rickard, J. E. (1991). Seasonal Effects on the Physicochemical Properties of Starch from Four Cultivars of Cassava. Starch/Starke, Vol. 43, pp. 455-459.

Asaoka, M., Blanshard, J. M. V., Rickard \& J. E. (1992). Effects of Cultivar and Growth Season on the Gelatinisation Properties of Cassava (Manihot esculenta) starch. J Sci Food Agri., Vol. 59, pp. 53-58.

Balagopalan, C., Padmaja, G., Nanda, S. K. \& Moorthy, S. N. (1988). Cassava in Food, Feed, and Industry. CRC Press, Inc., Florida. 205 p.

Breuninger, W. F, Piyachomkwan, K. \& Sriroth, K. (2009). Tapioca/cassava Starch: Production and use. In: Starch chemistry and technology, BeMiller, J. \& Whistler, R. 3rd ed. Academic press, New York. p 544.

Charles, A. L., Sriroth, K. \& Huang, T. (2005). Proximate Composition, Mineral Contents, Hydrogen Cyanide and Phytic Acid of 5 Cassava Genotypes. Food Chemistry, Vol. 92, No. 4, pp. 615-620.

Charles, A. L., Huang, T. C. \& Chang, Y. H. (2008). Structural Analysis and Characterization of a Mucopolysaccharide Isolated from Roots of Cassava (Manihot esculenta Crantz L.). Food Hydrocolloids, Vol. 22, No. 1, pp. 184-191.

Dai, D., Hu, Z., Pu, G., Li, H. \& Wang, C. (2006). Energy Efficiency and Potential of Cassava Fuel Ethanol in Guangxi Region of China. Energy Conversion $\mathcal{E}$ Management, Vol. 47, pp. 1686-1699.

Defloor, I., Swennen, R., Bokanga, M., \& Delcour, J.A. (1998). Moisture Stress During Growth Affects the Breadmaking and Gelatinisation Properties of Cassava (Manihot esculenta Crantz) Flour. J Sci Food Agri., Vol. 76, pp. 233-238.

Department of Alternative Energy Development and Efficiency [DEDE]. (2009). Alternative energy: Gasohol. Ministry of Energy. Available source: http:/ / www.dede.go.th.

FO Lichts. (2006). An F.O. Licht Special Study: World Ethanol Market: The Outlook to 2015. F.O.Licht Calvery Road, Tunbridge Wells, Kent, UK. p. 197.

Food and Agriculture Organization (FAO). 2011. Available from http://www.faostat.fao.org/site/339.

Fernando, S; Adhikari, S; Chandrapal, C; \& Murali, N. (2006). Biorefineries: Current Status, Challenges, and Future Direction. Energy \& Fuels, Vol. 20, pp. 1727-1737. 
Howeler, R. H. (2001). Cassava Agronomy Research in Asia: Has it benefited Cassava Farmers?, Proceedings of $6^{\text {th }}$ Regional Workshop: Present Situation and Future Research and Development Needs, pp. 345-382, Ho Chi Minh city, Vietnam, Feb 2125, 2000.

Howeler, R. H. (2007). Agronomic Practices for Sustainable Cassava Production in Asia, Proceedings of $7^{\text {th }}$ Regional Workshop: Cassava Research and Development in Asia: Exploring New Opportunities for an Ancient Crop, pp. 288-314, Bangkok, Thailand, Oct 28-Nov 1, 2002.

Huang, H., Ramaswamy, S., Tschirner, U. W., \& Ramarao, B.V. (2008). A Review of Separation Technologies in Current and Future Biorefineries. Separation and Purification Technology, Vol. 62, pp. 1-21.

Juliano, B.O. (1993). Rice in Human Nutrition. FAO Food and Nutrition Series No. 26. The International Rice Research Institute (IRRI) and food and agriculture organization of United Nations [FAO].

Kajiwara, S. \& Maeda, H. (1983). The Monosaccharide Composition of Cell Wall Material in Cassava Tuber (Manihot utilissima). Agric. Biol. Chem., Vol. 47, No. 10, pp. 235-2340.

Martinez-Gutierrez, R., Destexhe, A., Olsen, H. S. \& Mischler, M. (2006). Mash Viscosity Reduction. US Patent 20060275882.

Menoli, A. V. \& Beleia, A. (2006). Starch and Pectin Solubilization and Texture Modification During Pre-cooking and Cooking of Cassava Root (Manihot esculenta Crantz). LWFood Science and Technology, Vol. 40, No. 4, pp. 744-747.

Monceaux, D. A. (2009). Alternative feedstocks for fuel ethanol production. In: The Alcohol Textbook: A Reference for the beverage, fuel and industrial alcohol industries, Ingledew, W. M., Kelsall, D. R., Austin, G. D. \& Kluhspies, C. Nottingham University Press, Nottingham. ISBN 978-1-904761-65-5. pp. 47-71.

Moorthy, S. N. \& Ramanujam, T. (1986). Variation in Properties of Starch in Cassava Varieties in Relation to Age of the Crop. Starch/Starke, Vol. 38, pp. 58-61.

Office of Agricultural Futures Trading Commission, AFTC. (2007). Cassava. http:/ / www.aftc.or.th.

Pardales, J. R., \& Esquibel, C. B. (1996). Effect of Drought During the Establishment Period on the Root System Development of Cassava. Jpn J Crop Sci., Vol. 65, No. 1, pp. 9397.

Piyachomkwan, K., Wansuksri, R., Wanlapatit, S., Chatakanonda, P. \& Sriroth, K. (2007). Application of Granular Starch Hydrolyzing Enzymes for Ethanol Production. In: Starch: Progress in Basic and Applied Science, Tomasik, P., Yuryev, V. P. \& Bertoft, E., Polish Society of Food Technologists, Poland, pp. 183-190.

Piyachomkwan, K., Wansuksri, R., Wanlapatit, S. and Sriroth, K. (2008). Improvement of Utilizing Fresh Cassava Roots as Feedstock for Fermentation Process by Cocktail Enzymes. National Center for Genetic Engineering and Biotechnology.

Rojanaridpiched, C. 1989. Cassava: Cultivation, Industrial Processing and Uses. Kasetsart University. Bangkok. 439p.

Rojanaridpiched, C., Kosintarasaenee, S., Sriroth, K., Piyachomkwan, K., Tia, S., Kaewsompong, S. \& Nitivararat, M. (2003). Development of Ethanol Production 
Technology from Cassava Chip at a Pilot Plant Scale. National Research Council of Thailand.

Santisopasri, V., Kurotjanawong, K., Chotineeranat, S., Piyachomkwan, K., Sriroth, K. \& Oates, C.G. (2001). Impact of Water Stress on Yield and Quality of Cassava Starch. Industrial Crops and Products, Vol. 13, No. 2, pp. 115-129.

Singh, V. \& Eckhoff, S. R. (1997). Economics of Germ Preparation for Dry-Grind Ethanol Facilities. Cereal Chemistry, Vol.. 74, No. 4, pp. 462-466.

Sriroth, K., Santisopasri, V., Petchalanuwat, C., Piyachomkwan, K., Kurotjanawong, K. \& Oates, C. G. (1999). Cassava

Starch Granule Structure-function Properties : Influence of Time and Conditions at Harvest on Four Varieties of Cassava Starch. Carbohydrate polymers, Vol. 38, No. 2, pp. 161170.

Sriroth, K., Piyachomkwan, K., Santisopasri, V. \& Oates, C. G. (2001). Environmental Conditions During Root Development: Indicator of Cassava Starch Quality. Euphytica, Vol. 20, No. 1, pp. 95-101.

Sriroth, K., Piyachomkwan, K., Wanlapatit, S., Thitipraphunkul, K. and Laddee, M. (2006). Study on Utilization of By-Products from Ethanol Process for Value Addition. The Department of Alternative Energy Development and Efficiency, Ministry of Energy.

Sriroth, K., Piyachomkwan, K., Keawsompong, S., Chatakanonda, P., Wanlapatit, S \& Wansuksri, R. (2007). Improvement of Ethanol Production from Cassava by Application of Granular Starch Hydrolyzing Enzymes. National Research Council of Thailand, Bangkok.

Sriroth, K., Piyachomkwan, K., Keawsompong, S. \& Wanlapatit, S. (2008). Production of Bioethanol from Cassava by Single Step Uncooked Process. Thai Patent, Priority Information Application No. 0801003407.

Sriroth, K., Piyachomkwan, K., Wanlapatit, S. \& Nivitchayong, S. (2010a). The Promise of a Technology Revolution in Cassava Bioethanol : From Thai Practice to the World Practice. Fuel. Vol. 89, pp. 1333-1338.

Sriroth, K. \& Piyachomkwan, K. (2010b). Processing of Cassava into Bioethanol. Proceedings of $8^{\text {th }}$ Regional Workshop: A New Future for Cassava in Asia: Its Use as Food, Feed and Fuel to benefit the poor, pp. 740-750, Vientiane, Lao PDR, Oct 20-24, 2008.

Swinkels, J. J. M. (1998). Industrial starch chemistry, AVEBE Brochure. The Netherlands

Tanticharoen, M. (2009). A Study on Potential Improvement of Crop Yields of Sugarcane, Cassava and Palm Oil for Biofuel Production: Application of technology and planting area expansion. Thailand Research Fund. 182p. Bangkok.

Thirathumthavorn, D. \& Charoenrein, S. (2005). Thermal and Pasting Properties of AcidTreated Rice Starch. Starch/Starke, Vol. 57, pp. 217-222.

Thomas, K.C., Hynes, S. H. \& Igledew, W. M. (1996). Practical and Theoretical Considerations in the Production of High Concentrations of Alcohol by Fermentation. Process Biochemistry, Vol. 31, No. 4, pp. 321-331.

Treadway, R.H. (1967). Manufacture of Potato Starch. In: Starch: Chemistry and Technology, Whistler, R.L. and Paschall EF, New York. p 90. 
Wahjudi, J., Xu, L., Wang, P., Buriak, P., Singh, V., Tumbleson, M. E., Rausch, K. D. \& Eckhoff, S. R. (2000). The "Quick Fiber" Process: Effect of Temperature, Specific Gravity and Percentage of Residual Germ. Cereal Chemistry, Vol. 77, No. 5, pp. 640644. 


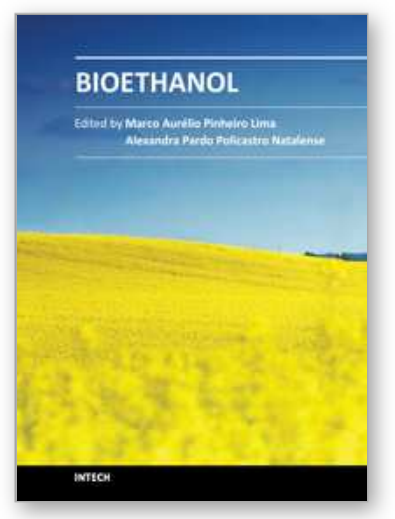

\author{
Bioethanol \\ Edited by Prof. Marco Aurelio Pinheiro Lima
}

ISBN 978-953-51-0008-9

Hard cover, 290 pages

Publisher InTech

Published online 01, February, 2012

Published in print edition February, 2012

Recent studies have shown strong evidence of human activity impact on the climate of the planet. Higher temperatures and intensification of extreme weather events such as hurricanes are among the consequences. This scenario opens up several possibilities for what is now called "green" or low carbon economy. We are talking about creating new businesses and industries geared to develop products and services with low consumption of natural resources and reduced greenhouse gases emission. Within this category of business, biofuels is a highlight and the central theme of this book. The first section presents some research results for first generation ethanol production from starch and sugar raw materials. Chapters in the second section present results on some efforts around the world to develop an efficient technology for producing secondgeneration ethanol from different types of lignocellulosic materials. While these production technologies are being developed, different uses for ethanol could also be studied. The chapter in the third section points to the use of hydrogen in fuel cells, where this hydrogen could be produced from ethanol.

\title{
How to reference
}

In order to correctly reference this scholarly work, feel free to copy and paste the following:

Klanarong Sriroth, Sittichoke Wanlapatit and Kuakoon Piyachomkwan (2012). Cassava Bioethanol, Bioethanol, Prof. Marco Aurelio Pinheiro Lima (Ed.), ISBN: 978-953-51-0008-9, InTech, Available from: http://www.intechopen.com/books/bioethanol/-cassava-bioethanol

\section{INTECH}

open science | open minds

\section{InTech Europe}

University Campus STeP Ri

Slavka Krautzeka 83/A

51000 Rijeka, Croatia

Phone: +385 (51) 770447

Fax: +385 (51) 686166

www.intechopen.com

\section{InTech China}

Unit 405, Office Block, Hotel Equatorial Shanghai

No.65, Yan An Road (West), Shanghai, 200040, China

中国上海市延安西路65号上海国际贵都大饭店办公楼405单元

Phone: +86-21-62489820

Fax: $+86-21-62489821$ 
(C) 2012 The Author(s). Licensee IntechOpen. This is an open access article distributed under the terms of the Creative Commons Attribution 3.0 License, which permits unrestricted use, distribution, and reproduction in any medium, provided the original work is properly cited. 